\title{
Eocene caviomorph rodents from Balsayacu (Peruvian Amazonia)
}

Myriam Boivin ${ }^{*}$, Laurent Marivaux², Walter Aguirre-Diaz ${ }^{3}$, Michele Andriolli Custódio ${ }^{4,5,6}$, Aldo Benites-Palomino ${ }^{3,7}$, François Pujos ${ }^{8}$, Martin Roddaz ${ }^{5,6}$, Rodolfo Salas-Gismondi ${ }^{3,9}$, Narla Stutz $^{2,10}$ Julia V. Tejada-Lara ${ }^{2,3}$, Johan Yans ${ }^{11}$ and Pierre-Olivier Antoine ${ }^{2}$

${ }^{1}$ Instituto de Ecorregiones Andinas (INECOA), Universidad Nacional de Jujuy, CONICET, IdGyM, Avenida Bolivia 1661, 4600 San Salvador de Jujuy, Jujuy, Argentina.

${ }^{2}$ Laboratoire de Paléontologie, Institut des Sciences de 1'Evolution de Montpellier (ISEM, UMR 5554, CNRS/UM/IRD/EPHE), Université de Montpellier, Place Eugène Bataillon, F-34095 Montpellier Cedex 5, France.

${ }^{3}$ Departamento de Paleontología de Vertebrados, Museo de Historia Natural - Universidad Nacional Mayor San Marcos (UNMSM, DPV-MUSM), Avenida Arenales 1256, Lima 14, Peru.

${ }^{4}$ Departamento de Geociências (DEGEO), Universidade Federal do Amazonas (UFAM) - Instituto de Ciências Exatas, Avenida Rodrigo Otávio, Japiim, 69077-000 Manaus, Brazil.

${ }^{5}$ Laboratorio de Geocronologia, Instituto de Geociências, Universidade de Brasília, Campus Universitário Darcy Ribeiro ICC - Ala Central, 70910-900 Brasília, Brazil.

${ }^{6}$ Géosciences-Environnement Toulouse (GET), Université de Toulouse, UPS (SVT-OMP), LMTG, CNRS, IRD, 14 Avenue Édouard Belin, F-31400 Toulouse, France.

${ }^{7}$ Paläontologisches Institut und Museum, Universität Zürich, Karl-Schmid-Strasse 4, 8006 Zürich, 
Switzerland.

8 Instituto Argentino de Nivología, Glaciología y Ciencias Ambientales (IANIGLA), CCTCONICET-Mendoza, Avenida Ruiz Leal s/n, Parque Gral. San Martín, 5500 Mendoza, Argentina.

${ }^{9}$ BioGeoCiencias Lab, Facultad de Ciencias y Filosofia/CIDIS, Laboratorios de Investigacion y Desarrollo (LID), Centro de Investigación para el Desarrollo Integral y Sostenible (CIDIS), Universidad Peruana Cayetano Heredia, Avenida Honorio Delgado 430, Lima 31, Peru.

10 Programa de Pós-Graduação em Geociências, Universidade Federal do Rio Grande do Sul, Avenida Bento Gonçalves 9500, 91501-970 Porto Alegre, Brazil.

${ }^{11}$ Department of Geology, Institute of Life, Earth and Environment (ILEE), Université of Namur, Rue de Bruxelles 61, 5000 Namur, Belgium.

*Corresponding author.

E-mail address: mboivin@idgym.unju.edu.ar

\section{ORCID numbers (available):}

Myriam Boivin: 0000-0002-5240-9460

Laurent Marivaux: 0000-0002-2882-0874

Michele Andriolli Custódio: 0000-0002-3543-8278

Aldo Benites-Palomino: 0000-0002-5409-6322

François Pujos: 0000-0002-6267-3927

Martin Roddaz: 0000-0001-8562-8582

Rodolfo Salas-Gismondi: 0000-0001-9990-8841 
Narla Stutz: 0000-0002-1937-3902

Julia V. Tejada-Lara: 0000-0003-2307-6764

Johan Yans: 0000-0001-7590-0298

Pierre-Olivier Antoine: 0000-0001-9122-1818

\section{Acknowledgments}

Many thanks to all the people that helped us in the field and in the lab. We are particularly grateful to our drivers Giancarlo, Manuel, and Percy, for their long-standing help during the yearly field seasons in the San Martín Department of Peruvian Amazonia. We warmly thank A. Assemat (ISEM, Montpellier, France) for taking photos of the specimens from TAR-55/TAR-55bis collected in 20152016; C. Cazeveille (Montpellier RIO Imaging, Institut des Neurosciences de Montpellier, France) for access to a scanning electron microscope facility; and C. Girard (ISEM) for access to a Leica binocular facility. We are indebted to A.-L. Charruault and S. Jiquel (ISEM) for the cast preparation of the rodent material from the Balsayacu section and from other Peruvian localities. This work was supported by The Leakey Foundation, the National Geographic Society, the "Investissements d'Avenir" grant managed by the "Agence Nationale de la Recherche" (CEBA, ANR-10-LABX-2501), and by the COOPINTEER CNRS/CONICET ( $\left.\mathrm{n}^{\circ} 252540\right)$ and the ECOS-SUD/FONCyT ( $\mathrm{n}^{\circ}$ A14U01) international collaboration programs. This work was carried out in the frame of the ongoing cooperation agreement between the "Museo de Historia Natural de la Universidad Nacional Mayor San Marcos" (Lima, Peru) and the "Institut des Sciences de l'Évolution de Montpellier-Université de Montpellier" (France). This is ISEM publication 2021X-032-Sud. 


\begin{abstract}
The Paleogene record of caviomorph rodents has substantially increased over the last decades, and their evolutionary history better understood by the discovery of their earliest representatives, so far recorded in several pre-Deseadan localities in Peruvian Amazonia. We report here the discovery of new caviomorph fossils from the Balsayacu area in Peru (TAR-55/TAR-55bis, TAR-76 and TAR77 localities, San Martín Department). The study of this new material reveals the occurrence of four caviomorph taxa in these localities: Balsayacuy huallagaensis gen. et sp. nov., Cachiyacuy aff. kummeli and Caviomorpha gen. et sp. indet. 1 and 2. It allows the revision and refinement of taxonomic assignments of previously described specimens. These four taxa have a primitive dental pattern, as that characterizing stem Caviomorpha recorded in pre-Deseadan localities of Peru (Eocene localities of Contamana and ?Late Eocene/Early Oligocene Santa Rosa). We support here an Eocene age for the Balsayacu section due to the complete absence of morphologically derived taxa representing modern caviomorph superfamilies. By the presence of derived characters in Balsayacuy and Cc. aff. kummeli compared to Canaanimys maquiensis and Cachiyacuy contamanensis from CTA-27 (Contamana, Peru; late Middle Eocene), the Balsayacu section may document a slightly younger time interval than CTA-27, likely documenting late Middle or early Late Eocene times. These low-latitude caviomorph faunas provide new insights into the early evolutionary history and paleodiversity of that group.
\end{abstract}

Keywords South America - Peru - Rodentia - Systematics - Biostratigraphy 


\section{Declarations}

Funding. This work was supported by The Leakey Foundation, the National Geographic Society, the "Investissements d'Avenir" grant managed by the "Agence Nationale de la Recherche" (CEBA, ANR-10-LABX-25-01), and by the COOPINTEER CNRS/CONICET ( $\left.{ }^{\circ} 252540\right)$ and the ECOSSUD/FONCyT ( ${ }^{\circ}$ A-14U01) international collaboration programs.

Conflicts of interest/Competing interests. We declare we have no competing interests.

Ethics approval. Not applicable.

Consent to participate. All authors consent to participate to this work.

Consent for publication. All authors consent to participate to this work.

Availability of data and material. The material is permanently stored in the Vertebrate Paleontological collection of the "Museo de Historia Natural, Universidad Nacional Mayor de San Marcos" (MUSM), Lima, Peru.

Code availability (software application or custom code). Not applicable.

Authors' contributions. Pierre-Olivier Antoine and Laurent Marivaux designed research; all authors contributed to the field effort; Laurent Marivaux prepared and took the photographs of the new specimens; Myriam Boivin and Pierre-Olivier Antoine made illustrations; Myriam Boivin performed taxonomic identifications and wrote the manuscript; Laurent Marivaux, Aldo Benites-Palomino, Michele Andriolli Custódio, François Pujos, Narla Stutz, Julia V. Tejada-Lara, Johan Yans and Pierre-Olivier Antoine critically revised the manuscript.

\section{Headings}

Eocene caviomorphs from Balsayacu 


\section{Introduction}

Due to a complex ecological and geological history, Amazonia is one of the regions of the world with the maximum biodiversity of many groups of organisms (Jenkins et al. 2013). Understanding the emergence of such biodiversity raises many questions surrounding its evolution, dynamics, the geographic origin of taxonomic groups that compose it, and factors that could have constrained and molded it (Stebbins 1974; Hoorn et al. 2010). Paleontological studies are fundamental to understand the evolutionary dynamics of this biodiversity, yet the fossil record of this geographic area had long been elusive. Indeed, owing to the dense vegetation cover, extensive recent alluvial depositions, aggressive alteration and pedogenesis, frequent landslides and seasonal floodings, fossiliferous outcrops are rare and of difficult access most of the time. In addition, field conditions are particularly harsh in such moist and warm climate environment. Since the end of the last century, thanks to field efforts driven by several scientific teams, many mammal-bearing localities were discovered in this region including Santa Rosa (Peru; ?Late Eocene/Early Oligocene; e.g., Campbell 2004), Cerro Colorado (Peru; Late Miocene-Late Pleistocene; Campbell et al. 2000, 2001, 2010), and Acre (Brazil; Late Miocene; e.g., Frailey 1986; Campbell et al. 2006; Negri et al. 2010; Kerber et al. 2017). Since 2003, our paleontological surveys in several areas of Peruvian Amazonia (i.e., Bagua, Contamana, Fitzcarrald, Iquitos-Nueva Unión, Juanjui, Madre de Dios, and Tarapoto) led to the discovery of numerous fossils providing a better knowledge of the Cenozoic record of many mammalian groups (e.g., Antoine et al. 2007, 2012, 2013, 2016, 2017; Goillot et al. 2011; Marivaux et al. 2012, 2016a,b, 2020; Bianucci et al. 2013; Pujos et al. 2013; Tejada-Lara et al. 2015; Boivin et al. 2017a,b, 2018a,b, 2019a). The fossil record of caviomorph rodents (Caviomorpha Wood, 1955) significantly increased after these discoveries, and understanding of their evolutionary history improved, especially for its earliest stages. Indeed, Peruvian Amazonia has yielded the earliest representatives of the group, so far recorded in several pre-Deseadan localities: Contamana (late 
Middle Eocene [ 41 Ma]; Antoine et al. 2012; Boivin et al. 2017a, 2019a,b), Balsayacu (late Middle Eocene; Assemat et al. 2019), Juanjui (late Middle Eocene-Early Oligocene; Assemat et al. 2019), Tarapoto-Shapaja (Late Eocene-Early Oligocene; Boivin et al. 2018a, 2019a,b; Assemat et al. 2019: fig. 7, p. 723), and Santa Rosa (Frailey and Campbell 2004; Arnal et al. 2020). Based on the evolutionary stages of its rodent assemblage (Frailey and Campbell 2004; Arnal et al. 2020), its metatherian fauna (Goin and Candela 2004) and the presence of some primates (Bond et al. 2015), a ?Late Eocene age was advocated for the mammal-bearing deposits of Santa Rosa. However, considering the entire mammalian fauna of that locality, and taking into account the fossil data assembled in recent years, notably from (bio)geographically close localities from Peruvian Amazonia, Santa Rosa is most likely earliest Oligocene in age (Shockey et al. 2004; Croft et al. 2008; Vucetich et al. 2010, 2015; Antoine et al. 2012, 2017; Kay 2015; De Vries and Seiffert 2017; Assemat et al. 2019; Seiffert et al. 2020).

During our 2018 and 2019 field seasons in Peruvian Amazonia, we returned to the Balsayacu area (San Martín Department, Peru), and collected larger amounts of sediments than previously found in TAR-55 and TAR-55bis fossil-bearing localities. Wet-screening of the sediments has allowed for the recovery of about thirty additional isolated rodent teeth. Additionally, in the same stratigraphic section, about a hundred meters below TAR-55, we discovered two new localities, TAR-76 and TAR-77, the samplings of which have yielded few dental remains of caviomorphs. The primary purpose of this contribution is to: (1) revise the caviomorph fauna from TAR-55 and TAR-55bis (Assemat et al. 2019) in light of the new material, and (2) describe the rodent material from the new localities TAR-76 and TAR-77. The systematic and biostratigraphical implications of these faunas are discussed. This work also includes the description of a new isolated tooth from CTA-27 (Contamana area, Loreto Department, Peru). The study of these caviomorph assemblages, among the oldest known in South American, allows further our understanding of the early evolutionary history and paleodiversity of the group. 


\section{Material and methods}

All the caviomorph dental specimens described herein (except MUSM 3943) originate from four localities in the vicinity of the small town of Balsayacu (San Martín Department, Peru; Fig. 1a): TAR-55, TAR-55bis, TAR-76, and TAR-77. These localities plus a fifth fossiliferous locality (TAR56) belong to the same stratigraphic section along the Huallaga River (Assemat et al. 2019; Fig. 1b, c). This section is assigned to the lower member of the Pozo Formation ("Pozo Sands"; late Middle Eocene) based on its fossil content, its stratigraphic position, and its lithological features (Assemat et al. 2019 and see below). TAR-55bis is located $1.5 \mathrm{~m}$ above TAR-55 and $121.5 \mathrm{~m}$ above TAR-56. TAR-76 and TAR-77 are situated between TAR-56 and TAR-55, TAR-76 is $165 \mathrm{~m}$ above TAR-56, and TAR-77 is $195 \mathrm{~m}$ above the latter. The localities of this section consist of poorly-consolidated microconglomerates with limestone nodules, soft pebbles and oxidized plant remains, organized into lenticular channels of decimetric thickness and of fluvial to fluvio-deltaic origin (Fig. 1c).

TAR-55 and TAR-55bis localities yielded charophytes, fossilized wood, seeds, ostracods, crabs, chondrichthyans, actinopterygians, chelonians, caimanine alligatorids, and mammals (metatherians and placentals). The biostratigraphic age of the Balsayacu section is supported by its similarity with the top of the fossiliferous sequence of the lower member of the Pozo Formation at Contamana (CTA-27-CTA-29; late Middle Eocene), notably due to the occurrence at the TAR-55 of the freshwater ray Potamotrygon ucayalensis also found at the Contamana sequence, but absent from younger deposits, either at Contamana or at Shapaja (Chabain et al. 2017; Boivin et al. 2018a). Moreover, the previous study of its caviomorph fauna revealed taxa close to those of the Eocene localities of Contamana (Cachiyacuy and Canaanimys; Assemat et al. 2019). Among the rodent taxa previously recorded in TAR-55 and TAR-55bis, none displayed an advanced evolutionary stage of 
their dental pattern (i.e., oblique loph(-id)s such as the chinchilloid Eoincamys) or incisive enamel microstructure (multiserial enamel subtype 2-3), contrary to the younger deposits of the region from Juanjui (TAR-49 and TAR-50; Assemat et al. 2019) and Shapaja (Boivin et al. 2018a, 2019a) areas. The biostratigraphic implications of the caviomorph fauna from TAR-55 and TAR-55bis in the context of this present work, are discussed in the section 'Age of TAR-55/TAR-55bis, TAR-76 and TAR-77' of the Discussion section (see p. XX). In addition to caviomorph teeth, crab and actinopterygian remains were found in TAR-76 and TAR-77. Finally, TAR-76 also yielded rests of wood, chelonians, metatherians and notungulates.

Since 2015, the material from TAR-55 and TAR-55bis was collected by excavating and screenwashing ( $1 \mathrm{~mm}$ mesh) a total of $610 \mathrm{~kg}$ of sediment. The caviomorph fossils from TAR-55 and TAR55bis, collected in 2015 and 2016, as a result of the processing of $133 \mathrm{~kg}$ of sediments, corresponds to nine isolated teeth, which were previously studied and figured in Assemat et al. (2019). In 2018 and $2019,465 \mathrm{~kg}$ of additional sediments were processed, allowing the discovery of 33 caviomorph teeth. As TAR-55 and TAR-55bis are levels with same geological characteristics, very close in position in the same outcrop, and yielding similar fossil contents, we chose to study the caviomorph material of these localities together. The localities TAR-76 and TAR-77 were discovered in 2019. In total, $75 \mathrm{~kg}$ of sediments for TAR-76 and $25 \mathrm{~kg}$ for TAR-77 were processed by screen-washing the same year.

The one isolated tooth from Contamana that we are describing (MUSM 3943) comes from the CTA-27 locality (late Middle Eocene; Antoine et al. 2012, 2016). CTA-27 is located on the northeastern flank of the Maquía Anticline and belongs to the lower member of the Pozo Formation (Antoine et al. 2016). It corresponds to inframetric channelized and unconsolidated sandstones, which include millimetric calcareous nodules of diagenetic origin locally encrusting fossil elements (Antoine et al. 2016). The fossil material from CTA-27 was collected by wet-screening ( 2 and $1 \mathrm{~mm}$ mesh) during previous field seasons (2008-2010). MUSM 3943 was recently found in unprocessed 
sediments and thus was neither included in the original description of the fauna (Antoine et al. 2012) nor in its revision (Boivin et al. 2017a). This tooth, attributed to Cachiyacuy kummeli, is included here because its occlusal pattern supports the similarity of taxa from Balsayacuy section with the genus Cachiyacuy, which has important biostratigraphic implications for the localities of this section (see Systematic Paleontology section).

All teeth described in this contribution are permanently stored in the Vertebrate Paleontological collection of the "Museo de Historia Natural, Universidad Nacional Mayor de San Marcos" (MUSM), Lima, Peru. The terminology for rodent dentition follows Boivin and Marivaux (2020) and the literature cited therein. Uppercase letters are used for upper dentition ( $\mathrm{dP}$, for decidual premolar; P, for premolar; M, for molar) and lowercase letters are used for lower dentition (dp, for decidual premolar; $\mathrm{p}$, for premolar; $\mathrm{m}$, for molar). The caviomorph taxa used for comparisons in this study are listed in Table 1. The list of the studied specimens from TAR-55/TAR-55bis, TAR-76 and TAR-77 is available in Table 2, which also includes the measurements made on this material (i.e., maximum anteroposterior length and maximum linguolabial width). For the material from TAR-55/TAR-55bis collected in 2015-2016, we used the measurements made by A. Assemat with a measuroscope Nikon 10 (Assemat et al. 2019). The rest of material was measured by M. Boivin from photos using TPSUtil and TPSDig softwares (Rohlf 2016). We used Adobe Illustrator CS4 (2008 Adobe Systems Incorporated) and CorelDRAW Graphics Suite X5 (2015 Corel Corporation) to create the figures.

Institutional abbreviations: LACM, Los Angeles County Museum, Los Angeles, USA; MUSM, Museo de Historia Natural de la Universidad Nacional Mayor San Marcos, Lima, Peru.

Other abbreviations: max length, maximum anteroposterior length; max width, maximum labiolingual width; SALMA, South American Land Mammal Age. 


\section{Systematic palaeontology}

Nomenclatural Remark: The new species and genus described below shall be referred to Boivin, 202X, following the article 50.1 and the "recommendation 50A concerning multiple authors" of the International Code of Zoological Nomenclature (ICZN 1999: p. 182).

Order Rodentia Bowdich, 1821

Suborder Ctenohystrica Huchon et al. 2000

Infraorder Hystricognathi Tullberg, 1899

Parvorder Caviomorpha Wood, 1955

Genus Balsayacuy gen. nov.

Etymology. From "Balsayacu", the Sub-Andean Peruvian village in the vicinity of which the type locality was discovered, and "cuy", which means guinea pig in Quechua language. The name Balsayacu refers to the balsa wood, Ochroma, with which the rafts are built and used to navigate the Huallaga River and other Amazonian rivers. As the new rodent Balsayacuy being probably one of the early stem Caviomorpha, its name is also in reference to the "raft" hypothesis to explain the dispersal and arrival of hystricognathous rodents in South America.

Type species. Balsayacuy huallagaensis sp. nov.

Species content. Only the type species. 
Geographic and stratigraphic distribution. Balsayacu (TAR-55/TAR-55bis and TAR-77 localities), San Martín Department, Pozo Formation, lower member (late Middle or early Late Eocene), Peru.

Generic diagnosis. As for the type and only known species.

Balsayacuy huallagaensis sp. nov.

Figures $2 \mathrm{a}-\mathrm{u}$, Table 2

2019 Cachiyacuy cf. kummeli Assemat et al. fig. 3C-E, p. 707.

2019 Canaanimys aff. maquiensis Assemat et al. fig. 4O, P, p. 711.

Etymology. From the Peruvian Huallaga River, which flows near the type locality.

Holotype. MUSM 3935, left M2 (Fig. 2k).

Referred material. MUSM 3373, 3921, left m1s (Assemat et al. 2019: fig. 3E, p. 707; Fig. 2d, g); MUSM 3922, 3923, right m1s (Fig. 2a, e); MUSM 3924, 3925, left m2s (Fig. 2h); MUSM 3926, 3927, right m2s (Fig. 2b, f); MUSM 3928, left m3 (Fig. 2c); MUSM 3929, right fragmentary P4 (Fig. 2i); MUSM 3930, right fragmentary upper molar (Fig. 2u); MUSM 3934, left fragmentary M1; MUSM 3931-3933, left M1s (Fig. 2j, m, p); MUSM 3377, right fragmentary M1 (Assemat et al. 2019: fig. 3C, p. 707; Fig. 2r); MUSM 3378, 3936, left M2s (Assemat et al. 2019: fig. 3D, p. 707; Fig. 2q, s); MUSM 3937, right M2 (Fig. 2n); MUSM 3379, left fragmentary M3 (Assemat et al. 2019: fig. 4P, p. 711; Fig. 2t); MUSM 3371, left M3 (Assemat et al. 2019: fig. 4O, p. 711; Fig. 2o); MUSM 3938, right M3 (Fig. 21). 
Type locality. TAR-55/TAR-55bis, Balsayacu, San Martín Department, Western Amazonia, Peru.

Other locality. TAR-77 (only for MUSM 3921), Balsayacu, San Martín Department, Western Amazonia, Peru.

Formation and age. Pozo Formation, lower member, late Middle Eocene to early Late Eocene (i.e., Barrancan or Mustersan SALMAs).

Diagnosis. Rodent characterized by brachydont and bunolophodont teeth, with a tendency to have a taeniodont pattern (pseudo-taeniodont pattern more frequently present). Subquadrate upper molars with strongly reduced or absent metaloph. If it is present, the metaloph is lingually free. Upper molars frequently with a long mesoloph faintly linked to the mesolophular spur or lingually free (the metalophular spur being absent). Accessory, thin and short enamel structures may be present between the third crest and the posteroloph, and connected to either or both transverse crests. Differs from Cachiyacuy, Eosallamys, Eoespina, and Eosachacui in displaying pseudo-taeniodont or taeniodont teeth. Differs from Cachiyacuy, Canaanimys and Eosallamys in having more quadrate upper molars. The metaloph is absent or reduced to a very short crest lingually free on upper molars of Huallagamys, differing from the most frequent morphology of this crest in Cachiyacuy, Canaanimys and Eosallamys, in which the metaloph is longer. Differs from Cachiyacuy, Canaanimys, Eosallamys, Eoespina, Eosachacui and Pozomys in having a mesoloph more frequently faintly linked to the mesolophular spur or lingually free. It furthers differs from Eoespina and Pozomys in having more important accessory structures between the third crest and the posteroloph on some upper molars.

Description. The lower molars (m1-3s) share the same dental structure (Fig. 2a-h). The m1s are clearly smaller than m2s. The unique identified m3 (MUSM 3928; Fig. 2c) has a similar width to that 
of $\mathrm{m} 1 \mathrm{~s}$, but it is longer than m1s and m2s. MUSM 3928 is distinguished by a lingual margin of the entoconid that is more labial in position to the mesiolingual corner of the tooth, and by showing a distal expansion and a labiolingual shortness of the posterolophid. The $\mathrm{m} 2 \mathrm{~s}$ have a trigonid and talonid with an equal width, as well as the m1s, but the latter can also show a shorter trigonid (MUSM 3922; Fig. 2a). Mesially, there is no trace of anterocingulid at the base of the crown. The protoconid is distally located with respect to the metaconid, and both are linked by a straight and continuous metalophulid I. The latter is lower in its labial part and connects to the mesiolingual slope of the protoconid. On MUSM 3373 (Fig. 2g), the metalophulid I corresponds to an anterior arm of the protoconid, which is linked to a longer anterior arm of the metaconid. On MUSM 3373, the metaconid bears a tiny cristulid, distally free on the anteroflexid (i.e., metaconid cristid). The molars show a strong development of the posterior arm of the metaconid, which is well connected to a mesostylid or to its anterior arm. In contrast, a deep and narrow furrow separates the mesostylid from the entoconid on m1-2s. On the MUSM $3928 \mathrm{~m} 3$, the mesostylid has a short, but strong posterior arm, which reaches the anterior arm of the entoconid, thus closing the mesoflexid lingually. The second transverse cristid can be straigth or slightly sinuous (S-shaped). It is somewhat difficult to describe it in some cases inasmuch as it appears continuous and without interruption or irregularities. However, on some teeth (MUSM 3373, 3921, and 3928; Fig. 2c, d, g), this cristid is formed by a long posterior arm of the protoconid, which is connected to a shorter neomesolophid. On MUSM 3923 (Fig. 2e), the neomesolophid is dominant and the posterior arm of the protoconid is short and thin. The ectolophid is complete and strongly mesiolabially directed, except on MUSM 3924, 3925, and 3927, in which it is more longitudinal (Fig. 2f, h). The hypoconid and entoconid are labiolingually opposed on MUSM 3921 and 3927, whereas the entoconid is more mesially situated than the hypoconid on other lower molars. These two cuspids are linked by a long and straight or slightly oblique hypolophid, which usually connects labially to a short anterior arm of the hypoconid (i.e., absence of taeniodont pattern). On MUSM 3923 and 3927, there are two very short cristulids, 
one on the distolabial margin of the hypolophid and the other stemming from the hypoconid (its anterior arm), both are clearly spaced, but are joined by the base. Due to the non-connection of these cristulids at their top, the hypoflexid is partly confluent with the metaflexid on this tooth (i.e, pseudotaeniodont). The entoconid can display anterior and posterior arms. When it is present, the anterior arm of the entoconid is thin and faintly visible (except on MUSM 3921), contrary to the posterior arm, which is usually stronger. It connects to the posteroloph (MUSM 3373, 3921, and 3926; Fig. 2b, d, g) or remains separated from the latter by a thin and shallow furrow (MUSM 3922, 3925, and 3927; Fig. 2a, f) or by a larger and deeper one (MUSM 3928; Fig. 2c). The hypoconid is mesiolingually-distolabially compressed and develops a strong and curved posterolophid. There is no hypoconulid. The anteroflexid and metaflexid are mesiodistally wide.

The MUSM 3929 P4 is moderately worn and mesiolabially broken (Fig. 2i). In occlusal view, its crown outline is round with a continuous surrounding crest, which forms the complete margin of the tooth. This surrounding crest is composed of a crestiform protocone, its posterior outgrowth, a minute hypocone, the anteroloph, and the posteroloph. It could also include an anterior arm of the hypocone, a mesostyle, and metacone. The labial protoloph is strong and distolingually oriented. Contrary to the straight and complete lingual protoloph, the mure is discontinuous and longitudinal. The anterior arm of the hypocone is more oblique than the labial protoloph and develops a mesolophular spur. There are longitudinal accessory crestules on the distolabial fossette (i.e., confluence of the mesial and distal mesoflexi with the metaflexus) extended labially to the mesolophular spur. They could be relics of a mesoloph and/or metaloph. The two other fossettes of the tooth are one small and mesiolabially-distolingually elongated parafossette and one expanded hypofossette.

M1-3s referred to Balsayacuy huallagaensis gen. et sp. nov. are brachydont and subquadrate (Fig. $2 \mathrm{j}-\mathrm{u})$. The M1s are the smallest upper molars, while the M2-3s are quite similar in size. The M3s (MUSM 3371, 3379, and 3938; Fig. 21, o, t) exhibit a smaller and more labial located hypocone with 
respect to the protocone than on $\mathrm{M} 1-2 \mathrm{~s}$ (Fig. $2 \mathrm{j}, \mathrm{k}, \mathrm{m}, \mathrm{n}, \mathrm{p}-\mathrm{s}$ ). On the less worn upper molars (MUSM 3371, 3377, and 3379), the main cusps are usually well defined, especially the cuspate paracone and mesostyle. The metacone can be well defined (MUSM 3371, 3935, and 3938; Fig. 2k, 1, o) or crestiform and poorly recognisable from the posteroloph (MUSM 3379 and 3931; Fig. 2j, t). The lingual protoloph is either complete (MUSM 3371, 3377, 3378, and 3937; i.e., non-taeniodont pattern; Fig. 2n, o, r, s), high (MUSM 3371) or low (MUSM 3377), reduced and limited to a tiny posterior arm of the protocone and/or crestule from the labial protoloph-mure junction (MUSM 3379, 3931, 3933, 3935, and 3938; i.e., pseudo-taeniodont pattern; Fig. 2j-m, t) or absent (MUSM 3932; i.e., taeniodont pattern; Fig. 2p). The protocone is mesiolingually-distolabially pinched and connected to a strong anteroloph. This mesial transverse crest runs labially and is separated from the paracone by a medium-sized furrow (MUSM 3371, 3379, 3933, and 3935) or connected to the mesial base of this cusp (MUSM 3378, 3931, 3932, 3937, and 3938). The labial protoloph is slightly oblique, whereas the mure is longitudinal (except on MUSM 3932). The third transverse crest is straight and strongly linked to an isolated mesostyle in most of cases. This crest is usually formed by either a long mesoloph connected to a short spur-like mesolophule (MUSM 3371, 3378, 3933, and 3935) or only by a long mesoloph lingually free (MUSM 3377 and 3930). On MUSM 3931, the configuration of the third crest is very peculiar: a long and straight mesolophule runs labially and remains isolated from the mesostyle, whereas the mesostyle bears, more distally, a long and distolingually oriented mesoloph, which is lingually free. The metaloph is usually absent. It is tiny but clearly distinct on MUSM 3938, in which two very short crestules originate from the posteroloph more labially. The more labially located crestule is recognized as a posteroloph spur. The MUSM 3937 displays a rounded structure on the posterior flexus, which probably corresponds to a residual metaloph. MUSM 3371, 3378, and 3935 have accessory structures (i.e., crestule(s) and/or cuspshaped structures) between the third crest and the posteroloph. These structures can be associated to a posteroloph spur (MUSM 3371 and 3378). They can be either isolated (MUSM 3371) or linked to 
the third crest (MUSM 3935) or to the third crest and posteroloph spur (MUSM 3378). The hypocone bears a low posterior arm, which faintly connects to the longer posteroloph.

Comparisons. By its brachydont teeth and subquadrate upper molars with a strong reduction or absence of the metaloph, Balsayacuy recalls Pozomys ucayalensis (CTA-29 and Santa Rosa; Boivin et al. 2017a; Arnal et al. 2020), Eoespina woodi and Eosachacui lavocati (Santa Rosa; Frailey and Campbell 2004). Some upper molars of these taxa can have a long mesoloph, more or less connected to a very short metalophule, as some specimens from TAR-55/TAR-55bis assigned to Balsayacuy. Particularly, the LACM 159207 M1 or M2 of P. ucayalensis (Arnal et al. 2020: fig. 4C, p. 203) displays the mesoloph less connected to the mesolophule, and in addition with a tiny crestule on its distolingual extremity directed towards (but not linked to) a posteroloph spur. The lower and upper molars of Balsayacuy tend to be taeniodont, a character found in P. ucayalensis. Nevertheless, the latter usually shows a more important degree of taeniodonty. Moreover, lower molars of Balsayacuy strongly differ from those of $P$. ucayalensis in having a complete metalophulid I connected to the protoconid. The presence of accessory crestules between the third transverse crest and the posteroloph on upper molars is a character also found in two basal caviomorphs from Peru: Cachiyacuy and Eosallamys (Eocene localities of Contamana, Balsayacu-Juanjui, and Santa Rosa; Frailey and Campbell 2004; Antoine et al. 2012; Boivin et al. 2017a; Assemat et al. 2019; Arnal et al. 2020). Besides, Cachiyacuy and Eosallamys can exhibit a long mesoloph faintly connected to a mesolophular spur, as well as a reduction of the metaloph. Although the more frequent configuration in Cachiyacuy contamanensis is a long metaloph terminating very close to the crestules between the third crest to the posteroloph (it can be connected to both crests or only to the posteroloph), some upper molars of this species have a more or less reduced metaloph, and the latter can be absent (MUSM 2244; Antoine et al. 2012; Boivin et al. 2017a). Upper molars of Cachiyacuy sp. cf. Cachiyacuy contamanensis from Santa Rosa (Arnal et al. 2020) have a reduced metaloph, but the 
latter is always more developed than on molars of Balsayacuy. In Eosallamys paulacoutoi (Santa Rosa; Frailey and Campbell 2004; Arnal et al. 2020), the metaloph can be more reduced as on MUSM 3938 from TAR-55/TAR-55bis. However, the upper molars of Cachiyacuy sp. cf. C. contamanensis and E. paulacoutoi always have a metaloph, and the latter is rarely lingually free. Cachiyacuy kummeli (CTA-27 and Santa Rosa; Antoine et al. 2012; Boivin et al. 2017a; Arnal et al. 2020) has upper molars with a metaloph lingually free, well-marked on M1s and M3s and reduced or absent on M2s (MUSM 2786 [Boivin et al. 2017a: fig. 4.13] and 3943 [Fig. 3p; see below]). Upper molars of Balsayacuy are smaller than those of Cc. contamanensis, Cachiyacuy sp. cf. C. contamanensis and E. paulacoutoi. Their size is similar to that of Cc. kummeli and Canaanimys maquiensis (CTA-27; Antoine et al. 2012; Boivin et al. 2017a). Balsayacuy differs from Cc. contamanensis, Cachiyacuy sp. cf. C. contamanensis, Cc. kummeli and E. paulacoutoi in having some some teeth developing a pseudo-taeniodont or taeniodont pattern. Some M3s of Cn. maquiensis and the LACM 159351 M1 of Canaanimys cf. Canaanimys maquiensis from Santa Rosa (Arnal et al. 2020: fig. 3A, p. 201) have a very short metaloph lingually free, but on their other upper molars, this crest turns forward and terminates close to the third crest and can connect to the latter. Finally, Balsayacuy differs from Cc. contamanensis, Cachiyacuy sp. cf. C. contamanensis, Cc. kummeli, Cn. maquiensis and E. paulacoutoi in having upper molars more quadrate. In summary, the dental material from TAR-55/TAR-55bis and TAR-77 defining Balsayacuy is characterized by a mosaic of traits principally shared with Cachiyacuy, Eosallamys and Pozomys. This combination of characters is somewhat singular, which leads us to propose here a new taxon: Balsayacuy huallagaensis gen. et sp. nov. 
Genus Cachiyacuy Antoine et al. 2012

Type species. Cachiyacuy contamanensis Antoine et al. 2012.

Species content. The type species and Cachiyacuy kummeli Antoine et al. 2012.

Geographic and stratigraphic distribution. Contamana (CTA-51, CTA-27, and CTA-29 localities), Loreto Department, Balsayacu (TAR-55/TAR-55bis localities) and Juanjui (TAR-46 and TAR-47 localities), San Martín Department, Pozo Formation, lower member (late Middle Eocene to early Late Eocene), Peru; Santa Rosa, Ucayali Department, "Yahuarango Formation” (?Late Eocene/Early Oligocene), Peru.

Cachiyacuy kummeli Antoine et al. 2012

Figure $3 p$

Holotype. MUSM 1882, left M1 (in Antoine et al. 2012, fig. 2m, p. 1322).

Referred material. MUSM 3943, left M2 (Fig. 3p).

Locality. CTA-27, Contamana, Loreto Department, Western Amazonia, Peru.

Formation and age. Pozo Formation, lower member, late Middle Eocene (i.e., Barrancan SALMA).

Description. The MUSM 3943 is brachydont and transverse-shaped (max length $=1.47 \mathrm{~mm}$; $\max$ width $=1.90 \mathrm{~mm}$; Fig. $3 p$ ). This upper tooth has a hypocone smaller than the protocone, and no posterior constriction, thereby suggesting it is a M2. The transverse crests (anteroloph, protoloph, 
mesolophule/mesoloph, and posteroloph) are thin. There is no conule. Lingually, the protocone is massive and distolabially-mesiolingually compressed. It displays a distolabially directed lingual protoloph, which connects to the long and slightly oblique labial protoloph (i.e., absence of taeniodont pattern). The anteroloph is long and barely curved. From the protocone, the anteroloph runs labially and reaches the paracone, and thus the paraflexus forms a labiolingually well-extended fossette. MUSM 3943 bears a thin and longitudinal mure, which connects the anterior arm of the hypocone to the protoloph lingually. The third transverse crest, strongly developed, links the anterior arm of the hypocone to a strong mesostyle, centrally situated in the labialmost margin of the crown. This crest is formed by the union of a long and straight mesoloph with a short and slightly distolabially oblique mesolophule. The mesostyle is mesially and distally isolated from the paracone and metacone, respectively. Due to the moderate degree of wear of the tooth, the metacone is not visible and seems to be fused with the posteroloph. A tiny metaloph is present on the mesial slope of the posteroloph and remains without lingual connection. The posteroloph shows a slight enlargement in its middle, probably corresponding to a minute posteroloph spur. On the posterior flexus (i.e., confluence of the distal mesoflexus with the metaflexus), MUSM 3943 shows an unusual crest, which is mesiolingually directed. It is faintly connected mesially to the third transverse crest, and distally to the posteroloph and its spur. This crestule may be a part of relictual connections of the metaloph to the third transverse crest and posteroloph.

Comparisons. By its brachydonty, non-taeniodonty, the presence of a metaloph and a connection, via crestule(s) between the third transverse crest and the posteroloph, MUSM 3943 recalls upper molars of the basal caviomorphs from Peru, Cachiyacuy and Eosallamys (Eocene localities of Contamana, Balsayacu-Juanjui, and Santa Rosa; Frailey and Campbell 2004; Antoine et al. 2012; Boivin et al. 2017a; Assemat et al. 2019; Arnal et al. 2020). MUSM 3943 is close to M2s of Cachiyacuy kummeli from CTA-27 and Santa Rosa (Antoine et al. 2012; Boivin et al. 2017a; Arnal et al. 2020) in having a 
similar size and in bearing an almost incipient metaloph. In particular, the morphology of MUSM 3943 is strongly reminiscent to that of MUSM 2786 of Cc. kummeli from CTA-27, which shows a similar crestule located between the third transverse crest and the posteroloph, and mesiolingually directed. Therefore, this tooth from CTA-27 is attributed to Cc. kummeli, which has been originally described in this locality.

\section{Cachiyacuy aff. kummeli}

Figure $3 \mathrm{a}-\mathrm{o}$, Table 2

2019 Cachiyacuy cf. kummeli Assemat et al. fig. 3A, B, F, G, p. 707.

Referred material. MUSM 3907, right p4 (Fig. 3c); MUSM 3908, 3909, left m1s (Fig. 3e); MUSM 3375, right fragmentary m1 (Assemat et al. 2019: fig. 3F, p. 707; Fig. 3d); MUSM 3374, right m1 (Assemat et al. 2019: fig. 3G, p. 707; Fig. 3b); MUSM 3910, right m2 (Fig. 3a); MUSM 3911, left fragmentary dP4 (Fig. 3j); MUSM 3372, left fragmentary P4 (Assemat et al. 2019: fig. 3A, p. 707; Fig. 3o); MUSM 3912, 3913, right fragmentary P4s (Fig. 3i); MUSM 3376, left fragmentary M1 (Assemat et al. 2019: fig. 3B, p. 707; Fig. 3n); MUSM 3915, right M1 (Fig. 3h); MUSM 3916, left M2 (Fig. 3m); MUSM 3917, 3918, right M2s (Fig. 3g, k); MUSM 3919, 3920, right M3s (Fig. 3f, 1).

Locality. TAR-55/TAR-55bis, Balsayacu, San Martín Department, Western Amazonia, Peru.

Formation and age. Pozo Formation, lower member, late Middle Eocene to early Late Eocene (i.e., Barrancan or Mustersan SALMAs). 
Description. The MUSM 3907 p4 is moderately eroded and shows digestion marks (Fig. 3c). It has rounded corners. The trigonid is wide, its width being about $70 \%$ of that of the talonid. With wear, the four main cuspids (i.e., metaconid, entoconid, protoconid, and hypoconid) are not discernable from the lophids, especially the protoconid and hypoconid areas, which correspond to large dentine platforms. The metaconid and protoconid areas are well separate. The metaconid develops mesiolabially a transverse and short anterior arm being separate from the protoconid by a wide and deep notch. Besides, the metaconid distally bears a short, but strong posterior arm, and labially a cristid (i.e., metaconid cristid), which straightly runs, then turns forward to connects to the labial extremity of the metalophulid I. There is no anterocingulid. The posterior arm of the metaconid reaches a mesostylid, which corresponds with wear to a lower and round structure of dentine, surrounded by enamel. Stemming from the protoconid area, the second transverse cristid is mostly mesially concave, being distalolingually directed toward the mesostylid and linked to that stylid. Thus, the second transverse cristid may be formed by two lophids: lingually, a very short cristid (= ?neomesolophid) and labially, a long and curved posterior arm of the protoconid. A thin cristid (= a neocristid or ?neomesolophid [if the second cristid is not formed by it]) runs from the distal part of the mesostylid and stays labially free. The ectolophid is strong and longitudinal, linking the protoconid to the long and roughly transverse hypolophid. The ectolophid being labially located, it delimits, with the protoconid, the hypoconid and its anterior outgrowth, a small hypoflexid, poorly extended labiolingually. A very short anterior arm of the hypoconid seems to be faintly connected to the hypolophid (i.e., non taeniodont pattern). The distal cristid formed by the fusion of the hypoconid, its anterior outgrowth and a strong and curved posterolophid, runs lingually and reaches the posterior arm of the entoconid. Moreover, a short cristulid on the metaflexid links the anterior margin of the posterolophid to the hypolophid. As a result of this double connection of the posterolophid with the entoconid-hypolophid, the metaflexid is lingually closed and divided into two subfossettids, a small and round lingual one and a labial one, more labiolingually extended. 
The lower molars are brachydont and quadrate or rectangular, being larger than long (Fig. 3a, b, d, e). The trigonid and talonid are roughly similar in width but the trigonid can be sligthly narrower than the talonid (MUSM 3374; Fig. 3b). The unique m2 identified (MUSM 3910; Fig. 3a), is larger than the m1s. All lower molars are tetralophodont and non-taeniodont (except MUSM 3910, see below). The metaconid, protoconid and hypoconid are crestiform, whereas the entoconid and mesostylid are in contrast highly cuspate. On the unworn MUSM $3374 \mathrm{~m} 1$, the protoconid, distolabially-mesiolingually pinched, is the highest cuspid of the tooth. The lower and smaller metaconid is positioned on the mesial margin of the tooth, and is mesiodistally compressed. This cuspid bears a strong and curved posterior arm faintly linked to a small mesostylid. On MUSM 3908, 3909, and 3910 (Fig. 3a, e), the protoconid and metaconid are linked by a strong and complete metalophulid I. On MUSM 3375 (Fig. 3d), the latter is formed by two cristids, a lingual long anterior arm of the metaconid connecting to a shorter labial anterior arm of the protoconid. On MUSM 3374, the protoconid is well separated from the anterior arm of the metaconid by a large and deep notch. The anterior arm of the protoconid is weakly discernable, being low and situated on the labial slope of the anterior arm of the metaconid. At the junction between the two anterior arms, a short cristid runs distolingually on the anteroflexid and then ends close to the base of a spur on the mesial margin of the second transverse cristid. MUSM 3375 and 3910 also show a very short spur on the mesial and distal margins of the second transverse cristid, respectively. The second cristid, connecting the mesostylid to the protoconid, is thin and S-shaped on MUSM 3910 and to a lesser extent on MUSM 3374, and distolingually directed on MUSM 3375. The ectolophid can be roughly longitudinal (MUSM 3374 and 3375; Fig. 3b, d), more oblique (MUSM 3908 and 3909; Fig. 3e), or aligned with the protoconid (MUSM 3910; Fig. 3a). The hypolophid is strong and transverse or slightly curved (MUSM 3374 and 3910). It is connected labially to a thin but high and complete anterior arm of the hypoconid. On MUSM 3910, there are two short cristulids: one on the distolabial margin of the hypolophid and the other stemming from the hypoconid (its anterior arm). These two cristulids are 
almost connected and separated by a very tiny notch (i.e, pseudo-taeniodont). The hypoconid has a long and mesiolabially oriented outgrowth. The entoconid is more mesially positioned with respect to the hypoconid, and bears a strong posterior arm, short on MUSM 3374 and longer on MUSM 3910. The posterolophid reaches the anterior arm of the entoconid and thus the metaflexid is closed lingually, forming a broad metafossettid.

The dP4 (MUSM 3911; Fig. 3j) is damaged and moderately worn. The paracone, labial protoloph, and most of the anteroloph are missing. It is rectangular, with a lingual margin appearing longer than the labial one. Among the present cusps/styles, only the mesostyle on the labial margin is clearly visible. The mesostyle is mesially and distally separate from the paracone and the lingual extremity of the posteroloph. The protocone corresponds to a large dentine platform due to wear. A lingual protoloph is strong and links the protocone to the mure (i.e., non-taeniodont pattern). The latter is complete and oblique, but not aligned with the anterior arm of the hypocone. The third transverse crest is straight and continuous. The metacone is not discernable, entirely subsumed within the posteroloph. On its mesial slope, it bears a tiny metaloph, which is lingually free. The posteroloph is long and curved. There are two accessory enamel crestules: one on the third crest and one on the posteroloph (i.e., posteroloph spur). These crestules are linked together and thus divide the posterior flexus (i.e., confluence between the distal mesoflexus and the metaflexus) into an extended lingual fossette and a smaller labial flexus.

Three specimens are fragmented P4s (MUSM 3372, 3912, and 3913; Fig. 3i, o). Being slightly broken on its labial margin, MUSM 3913 is the most complete of the three (Fig. 3i). MUSM 3912 is damaged labially and lingually and the central part of MUSM 3372 is missing. MUSM 3372 and 3913 are oval in occlusal outline. With its paracone more lingually situated than the mesostyle and metacone, MUSM 3372 (Fig. 3o) shows a mesial part narrower than its distal part. The labial cusps/styles are well defined, whereas the protocone and hypocone are strongly crestiform. Via its long and curved posterior outgrowth, the protocone is twinned with the hypocone, forming a 
protocone-hypocone complex that closes the hypoflexus lingually. The anteroloph, low and short, remains separate from the paracone (MUSM 3372 and 3913) or reaches the base of this cusp (MUSM 3912). The paracone is clearly the largest cusp and displays a strong and oblique labial protoloph. The lingual extremity of the labial protoloph is mesially connected to a complete and distolabially directed lingual protoloph and distally to a high and longitudinal mure. On MUSM 3372 , the mesostyle and metacone are equal-sized. The mesostyle is separate from the paracone by a very thin furrow and it is faintly connected to the labial extremity of the posteroloph. The metacone, sligthly less distinct, is subsumed within the long posteroloph. Due to the advanced stage of wear of MUSM 3913 (Fig. 3i), the mesostyle, metacone and their potential associated lophs (i.e., mesoloph and metaloph, respectively) are not discernable on this tooth. They are probably subsumed within the posteroloph, forming a posterior broad dentine platform. On this $\mathrm{P} 4$, there is two short crestules on the anterior arm of the hypocone, forwardly a mesolophule and backwardly a neocrestule lingually free. The mesolophule appears to have two connections with the posterior platform, which could be with a mesoloph stemming from the mesostyle and a metaloph from the metacone. Despite of its fragmentary state, MUSM 3372 (Fig. 3o) shows a third transverse crest, probably complete, a metaloph, and a tiny damaged crest on the anterior arm of the hypocone backward to the third crest. This damaged crest being aligned with the metaloph, which seems to be unconnected to the posteroloph, might be a rest of a connection of the metaloph with the anterior arm of the hypocone. Another hypothesis is that it could be a neocrest lingually free as on MUSM 3913.

The upper molars referred here to Cachiyacuy aff. kummeli are brachydont, transverse and nontaeniodont (Fig. $3 \mathrm{f}-\mathrm{h}, \mathrm{k}-\mathrm{n}$ ). M2s are larger than M1s and M3s, and M1s are the smallest upper molars. The M3s differ from other upper molars in having a hypocone clearly displaced much more labially. On the nearly pristine M2 (MUSM 3916; Fig. 3m), the protocone, strongly mesiolinguallydistolabially pinched, is not discernable from its anterior arm and its posterior outgrowth, forming a high curved crest on the mesiolingual corner of the tooth. This crest, as well as the hypocone and its 
anterior and posterior arms, are the highest structures of the tooth. The anterior arm of the protocone and posterior arm of the hypocone are connected to a low and long anteroloph and posteroloph, respectively. The anteroloph can remain separate from the paracone by a tiny and shallow furrow (MUSM 3376 and 3916-3918; Fig. 3g, k, m, n) or can be faintly connected to this cusp (MUSM 3919; Fig. 3f). On MUSM 3917 (Fig. 3g), the labial extremity of the anteroloph is enlarged and could correspond to a parastyle. With wear, the posterior outgrowth of the protocone becomes longer especially on M2s and M3s. As a result of the development of a long posterior outgrowth of the protocone on these molars, the hypoflexus is more mesiodistally constricted. On MUSM 3916, the lingual protoloph is low, but strong and complete. The labial protoloph is slightly oblique (i.e, mesiolabially directed) and the third transverse crest can be straight or parallel to the labial protoloph (MUSM 3919; Fig. 3f). The third crest is composed of a long mesoloph stemming from the mesostyle associated with a metalophular spur originating on the anterior arm of the hypocone. The mure is usually roughly longitudinal, but it can be more oblique as on M3s and MUSM 3916. On MUSM 3376 and 3916 (Fig. 3m, n), the mure is uncomplete because unconnected to the labial protoloph. On the labial margin, the mesostyle and the paracone are well defined and bulbous, the latter cusp being very large and protruding. These two cusps remain separate on all upper molars, usually by a tiny furrow except on MUSM 3916, in which there is an additional cusp-shaped structure (neocusp) between the paracone and the mesostyle. On this tooth, between this neocusp and the mesostyle, a long neocrest is developed and remains lingually free. Due to the presence of this neocrest, the third crest appears more distally located, notably in its lingual part. On MUSM 3917, a metacone is present on the distolabial corner of the tooth and displays thin anterior and posterior arms as well as a short metaloph lingually free. On other upper molars, there is no distinct metacone, the latter being probably subsumed within the posteroloph. There is no conule. The posteroloph bears a posteroloph spur, almost incipient (MUSM 3916; Fig. 3m) or more developed (MUSM 3917, 3918, and 3919; Fig. 3f, g, k). It can reach a neocrestule or a net of neocrestules connected to the 
mesoloph-mesolophule junction (MUSM 3917 and 3918) or can be free (MUSM 3916 and 3919). In the latter case, it can end close to the neocrestules stemming from the mesoloph-mesolophule junction (MUSM 3916; Fig. 3m).

Remark. Although the MUSM 3376 M1 (Fig. 3n) is fragmentary, it has a smaller size with respect to the other M1s assigned to Cachiyacuy aff. kummeli. Owing its characters similar to the other upper molars of Cachiyacuy aff. kummeli (i.e., brachydonty, transversality, non-taeniodonty, third crest corresponding to a long mesoloph associated with a metalophular spur, and neocrestules between the third crest and the posteroloph), we consider that MUSM 3376 would have documented a small individual of this taxon.

Comparisons. The morphology of this taxon from TAR-55/TAR-55bis is strongly reminiscent of that found in two basal caviomorph representatives, Cachiyacuy and Eosallamys, from Peru (Eocene localities of Contamana, Balsayacu-Juanjui, and Santa Rosa; Frailey and Campbell 2004; Antoine et al. 2012; Boivin et al. 2017a; Assemat et al. 2019; Arnal et al. 2020). By its brachydonty, notaeniodonty, the presence of a metaloph on some upper teeth and a connection via crestules (included crestule from the third crest and posteroloph spur) between the third transverse crest and the posteroloph on $\mathrm{dP} 4 \mathrm{~s}$ and some upper molars, this taxon from TAR-55/TAR-55bis is close to Cachiyacuy contamanensis from CTA-27 (Contamana, Peru; late Middle Eocene; Antoine et al. 2012; Boivin et al. 2017a), Cachiyacuy sp. cf. Cachiyacuy contamanensis and Eosallamys paulacoutoi from Santa Rosa (Peru, ?Late Eocene/Early Oligocene; Frailey and Campbell 2004; Arnal et al. 2020), and Cachiyacuy kummeli from both localities (Antoine et al. 2012; Boivin et al. 2017a; Arnal et al. 2020). The M1-2s of Cc. contamanensis usually have a well-marked metaloph longer than on MUSM 3917, the unique upper molar from TAR-55/TAR-55bis that distinctly bears 
this crest. In most cases, Cc. contamanensis has upper molars bearing a metaloph that ends very close to the crestules linking the third crest to the posteroloph (it can be connected to them), or that is only connected to the posteroloph (via crestules or not). Conversely, the short metaloph, which remains lingually free on MUSM 3917, is remote from these crestules. However, in Cc. contamanensis, the M3s show more frequently a reduction of the metaloph, whereas its M1-2s exhibit a high morphological variation of this crest in terms of development and connections. Indeed, on some M1-2s, the metaloph can be reduced to a short crest or a very short spur, or absent (MUSM 2244), and can be lingually free and far from the crestules between the third crest and the posteroloph (MUSM 2742), as in the material from TAR-55/TAR-55bis. The length of the metaloph of M1-2s of Cachiyacuy sp. cf. C. contamanensis from Santa Rosa is shorter than in Cc. contamanensis but usually longer than in the material from TAR-55/TAR-55bis, in which the metaloph has a development more similar to the configuration of E. paulacoutoi. The LACM 159241 M1 or M2 of Cachiyacuy sp. cf. C. contamanensis and several upper molars of E. paulacoutoi (LACM 143267, 144302, 149494, and 160206) show a similar morphology to that of MUSM 3917 from TAR-55/TAR-55bis and MUSM 2742 from CTA-27 in having a reduced metaloph remote from the crestules between the third crest and the posteroloph. Nevertheless, neither Cachiyacuy sp. cf. C. contamanensis nor E. paulacoutoi have an upper molar without metaloph, contrary to MUSM 3916 and 3919 from TAR-55/TAR-55bis. The other upper molars of Cachiyacuy sp. cf. C. contamanensis and E. paulacoutoi have a metaloph connected to both the third crest and the posteroloph (LACM 143376, 143380, 159245 and the LACM 143422 M2-3), or only to the third crest (LACM 159243, 159240, 143363 and the LACM 143422 M1). The material from TAR55/TAR-55bis differs from Cc. contamanensis, Cachiyacuy sp. cf. C. contamanensis and E. paulacoutoi in having a smaller size, similar to that of Cc. kummeli, Canaanimys maquiensis from CTA-27 (Antoine et al. 2012; Boivin et al. 2017a) and Balsayacuy huallagaensis gen. et sp. nov. described above. The metaloph of $C$. kummeli is usually reduced or almost absent and lingually free 
on M1s, and more developed and tends to connect to the posteroloph (via a potential very short posteroloph spur) on M2s. On upper molars of this species, there is no crestule that tend to link the third crest to the posteroloph, except on two M2s, MUSM 2786 (Boivin et al. 2017: fig. 4.13) and 3943 (Fig. 3P; see above), similar to the upper molars from TAR-55/TAR-55bis. MUSM 2786 does not have any metaloph, whereas MUSM 3943 diplays a very short metaloph. On M1-2s of $C n$. maquiensis, the metaloph is long, turned forward and ends close to the third crest, and can connect to the latter. In comparison to this material from TAR-55/TAR-55bis, the upper molars of $B$. huallagaensis from the same locality show a more frequent tendency to have a taeniodont pattern, a mesoloph disconnected to the anterior arm with the reduction/absence of the mesolophule, and a reduction/absence of the crestules between the third crest and the posteroloph. The material from TAR-55/TAR-55bis differs from all taxa mentioned above, as well as from Eoespina woodi and Eosachacui lavocati (Santa Rosa; Frailey and Campbell 2004), in having more transverse lower molars and with a more important discontinuity of the metalophulid I close to the protoconid; from B. huallagaensis, E. woodi, E. lavocati and Pozomys ucayalensis (CTA-29 and Santa Rosa; Boivin et al. 2017a; Arnal et al. 2020) in having more transverse upper molars; from $E$. woodi and $P$. ucayalensis in having some upper molars with a connection between the third crest and the posteroloph; and from P. ucayalensis in having more transverse lower molars and a pattern, which tends to be more non-taeniodont with the presence of strong anterior arm of the hypoconid on lower molars and lingual protoloph on upper molars. In conclusion, the upper molars from TAR-55/TAR55bis are included in the morphological variation of $C$. contamanensis, Cachiyacuy sp. cf. $C$. contamanensis, E. paulacoutoi and Cc. kummeli, and appear closer to the latter species. Owing its particular characters on lower molars and the low quantity of upper molars attributed to Cc. kummeli, preventing a good assessment of the morphological variation in this species, we prefer keep the dental material from TAR-55/TAR-55bis in open nomenclature, as Cachiyacuy aff. kummeli. 
Caviomorpha gen. et sp. indet. 1

Figure $3 g, r$, Table 2

Referred material. MUSM 3939, right labial fragment of lower molar (Fig. 3q); MUSM 3940, left P4 (Fig. 3r).

Locality. TAR-55/TAR-55bis, Balsayacu, San Martín Department, Western Amazonia, Peru.

Formation and age. Pozo Formation, lower member, late Middle Eocene to early Late Eocene (i.e., Barrancan or Mustersan SALMAs).

Description. MUSM 3939 is a right labial fragment of a moderately worn lower molar, in which only the protocone area and the labial parts of the hypoflexid and the anterior outgrowth of the hypocone are preserved (Fig. 3q). The anterior outgrowth of the hypocone seems to be mostly labially directed and the hypoflexid does not show any mesiodistal constriction. These characters suggest that this damaged tooth would be a labial fragment of lower molar instead of a lingual fragment of upper molar.

MUSM 3940 is an eroded, labially broken and moderately worn P4 (Fig. 3r). The anteroloph, paracone, and the labial part of the labial protoloph are missing. MUSM 3940 is non-taeniodont and could be tetralophodont. The protocone displays a strong posterior arm (or lingual protoloph) connected to the labial protoloph and a long and curved posterior outgrowth. The latter reaches the anterior arm of a minute hypocone. As it is not confluent with the paraflexus and given it is lingually closed, the hypoflexus forms a fossette mesiodistally extended. The mure is long, longitudinal, and composed of two linked crests, a strong mesial one stemming from the labial protoloph and a thinner 
distal one that runs from the oblique anterior arm of the hypocone. The third transverse crest is straight and distally situated, close to the posteroloph. Because of the position of the third crest, the mesial mesoflexus is well expanded. Conversely, the posterior flexus is strongly reduced (i.e., confluence of the distal mesoflexus with the metaflexus). All the preserved labial structures are connected, and thus, the mesial mesoflexus and the posterior flexus form two fossettes.

Comparisons. Despite their very fragmentary nature, these two specimens document the presence of a medium-sized species, which is the largest taxon to be recorded at TAR-55/TAR-55bis. The MUSM 3940 P4 is comparable in size to the P4s attributed to Eobranisamys javierpradoi from CTA27 (Contamana, Peru; late Middle Eocene; Boivin et al. 2017a). By its characters (i.e., possible tetralophodont pattern, transverse crest distally positioned, and a labial link between the labial protoloph, the third crest and the posteroloph), MUSM 3940 has a morphological pattern close to that of the P4s of E. javierpradoi (Antoine et al. 2012: fig. 2a', p. 1322; Boivin et al. 2017a). However, a typical character of E. javierpradoi, the taeniodonty of its upper molars, is not present on MUSM 3940. Hence, we provisionally refer the material of TAR-55/TAR-55bis to as Caviomorpha gen. et sp. indet. 1 .

Caviomorpha gen. et sp. indet. 2

Figure $3 \mathrm{~s}$, t, Table 2

Referred material. MUSM 3941, left posterior fragment of p4 (Fig. 3s); MUSM 3942, right m1 or m2 (Fig. 3t). 
Locality. TAR-76, Balsayacu, San Martín Department, Western Amazonia, Peru.

Formation and age. Pozo Formation, lower member, late Middle Eocene to early Late Eocene (i.e., Barrancan or Mustersan SALMAs).

Description. MUSM 3941 is a fragment corresponding to the posterior part of a p4, bearing digestion marks (Fig. 3s). Only the entoconid, hypolophid, hypoconid, its anterior arm and outgrowth, and the posterolophid are preserved. Mesially, the tooth shows a rest of a transverse cristid, probably of a neomesolophid or posterior arm of the protoconid. The entoconid is bulbous and bears a roughly straight hypolophid. From the crestiform hypoconid, its anterior arm reaches the labial extremity of the hypolophid (i.e., non-taeniodnt pattern). The anterior outgrowth of the hypoconid is short, strong, and labiomesially directed. MUSM 3941 is characterized by a posterolophid strongly curved and connected to the posterior slope of the entoconid.

MUSM 3942 is a $\mathrm{m} 1$ or a $\mathrm{m} 2$ showing a very advanced stage of wear, characterized by cuspids/stylids entirely subsumed within the lophids and by all flexids closed (Fig. 3t). The tooth is tetralophodont and non-taeniodont. The protoconid and hypoconid areas correspond to enlarged dentine platforms. The second cristid and the hypolophid are distolingually oblique. The metaflexid and hypoflexid are round-oval, whereas the anteroflexid and mesoflexid are more labiolingually extended.

Comparisons. The size of these two teeth from TAR-76 is similar to that of Balsayacuy huallagaensis gen. et sp. nov. and Cachiyacuy aff. kummeli from TAR-55/TAR-55bis. MUSM 3942 is tetralophodont, as the lower molars of B. huallagaensis and Cc. aff. kummeli. The two lower teeth from TAR-76 have a non-taeniodont pattern, as $C c$. aff. kummeli and some lower teeth of $B$. huallagaensis. However, the fragmentary nature of MUSM 3941 and the advanced stage of wear of 
MUSM 3942 do not allow to conclude regarding the determination of this material as $B$. huallagaensis or Cc. aff. kummeli.

\section{Discussion}

\section{A single caviomorph assemblage at TAR-55/TAR-55bis, TAR-76 and TAR-77}

Two taxa were previously described at TAR-55/TAR-55bis: Cachiyacuy cf. kummeli and Canaanimys aff. maquiensis (Assemat et al. 2019). The study of the new material from these localities has allowed for a taxonomic revision of the rodent fauna from TAR-55/TAR-55bis. Three taxa are currently recognized: Balsayacuy huallagaensis gen. et sp. nov. (synonymous with Canaanimys aff. maquiensis sensu Assemat et al. 2019 and partly with Cachiyacuy cf. kummeli sensu Assemat et al. 2019), Cachiyacuy aff. kummeli (partly synonymous with Cachiyacuy cf. kummeli sensu Assemat et al. 2019) and Caviomorpha gen. et sp. indet. 1. Balsayacuy huallagaensis also occurs at TAR-77. Despite the fragmentary nature and the advanced stage of wear of the material from TAR-76, here referred to as Caviomorpha gen. et sp. indet. 2, it ressembles both $B$. huallagaensis and Cc. aff. kummeli. This would attest to a short time interval between all the localities from the upper part of the stratigraphic section (within $90 \mathrm{~m}$-thick section), and to similar conditions regarding depositional and/or local environment. Hence, the concerned assemblages could be considered as a single local assemblage. All the recorded taxa share dental characters, considered as plesiomorphic in caviomorphs: small size, brachydonty, bunolophodonty, thin and transverse loph(-id)s, tetralophodont lower molars, and presence of a metaloph on upper molars (Antoine et al. 2012; Boivin et al. 2017a, 2019b; Boivin and Marivaux 2020). These three taxa show strong affinities with basal caviomorphs found in pre-Deseadan localities of Peru, especially in CTA-27 
(Contamana, late Middle Eocene; Antoine et al. 2012; Boivin et al. 2017a) and, to a lesser extent, Santa Rosa (Frailey and Campbell 2004; Arnal et al. 2020). By having some upper molars bearing accessory structures between the third transverse crest and the posteroloph, and which tend to connect to both transverse crests, Balsayacuy and Cc. aff. kummeli are particularly close to Cachiyacuy and Eosallamys from CTA-27 and Santa Rosa. However, contrary to Balsayacuy and Cc. aff. kummeli, in which the metaloph is absent or strongly reduced and lingually free, Cachiyacuy contamanensis and Eosallamys paulacoutoi have a longer metaloph, which ends very close to these accesory structures or that is connected to them in most cases. Within caviomorphs, a connection between the third crest and the metaloph is unusual, and otherwise found only in Canaanimys maquiensis from CTA-27 and Canaanimys cf. C. maquiensis from Santa Rosa (Antoine et al. 2012; Boivin et al. 2017a; Arnal et al. 2020). As previously noted (Antoine et al. 2012; Boivin et al. 2017a), in non-caviomorph hystricognathous rodents, some earliest African-Asian hystricognaths ("protophiomyines", "baluchimyines", and "bugtimyids"; Marivaux and Boivin 2019) are characterized by this connection (e.g., Baluchimys, Hodsahibia, Bugtimys, Protophiomys, Walsamys), but some others "phiomyids" also have a double connection of the metaloph with the third crest and the posteroloph (e.g., Acritophiomys, Phiomys, Phenacophiomys). As a result, these species from CTA-27 (i.e., Cn. maquiensis and Cc. contamanensis) and to a lesser extent some taxa from Santa Rosa (i.e., Canaanimys cf. C. maquiensis, Cachiyacuy cf. C. contamanensis, and E. paulacoutoi; because they have M1-2s with a more reduced metaloph than in species from CTA-27) appear to be the caviomorph taxa so far known with a strongly reminiscent occlusal morphology with these African-Asian basal hystricognaths. Moreover, Balsayacuy shares some characters with other taxa from CTA-29 (another Eocene locality from Contamana) and Santa Rosa: Eoespina woodi, Eosachacui lavocati and Pozomys ucayalensis (Frailey and Campbell 2004; Boivin et al. 2017a; Arnal et al. 2020). According to the recent phylogenetic analyses of Boivin et al. (2019b), these species are resolved as basal representatives of caviomorphs (early stem Caviomorpha). 
Finally, Caviomorpha gen. et sp. indet. 1 from TAR-55/TAR-55bis exhibits some affinities with Eobranisamys javierpradoi from CTA-27 (Boivin et al. 2017a), a species also recently recognized as a stem caviomorph (Boivin et al. 2019b). In conclusion, all three rodent taxa from TAR-55/TAR55bis would likely be basal representatives of caviomorphs. Balsayacuy and Cc. aff. kummeli seem to have slightly more advanced morphology of their M1-2s over Cn. maquiensis, Cc. contamanensis and E. paulacoutoi by showing a metaloph that is either absent or strongly reduced and lingually free.

\section{Age of TAR-55/TAR-55bis, TAR-76 and TAR-77}

Although three taxa are henceforth recognized at TAR-55/TAR-55bis and they are different from those described before (see Assemat et al. 2019), they are strongly similar with some basal caviomorph representatives, suggesting an old age for these localities, as proposed by Assemat et al. (2019). According to these authors, these localities would be late Middle Eocene in age owing to their species resemblance with the late Middle Eocene localities of Contamana (in particular with CTA-27), and the absence of taxa with more derived dental characters and representatives of modern superfamilies of caviomorphs, even as dental fragments (Boivin et al. 2019b). The younger deposits of the region (TAR-49 and TAR-50, Juanjui area) record taxa evolutionarily more advanced, with an occlusal morphology characterized by a marked obliquity of loph(-id)s (the chinchilloid Eoincamys), and some with incisors having already achieved a multiserial enamel subtype 2-3 (Assemat et al. 2019). Eoincamys was originally described in Santa Rosa (Frailey and Campbell 2004) and subsequently in the localities of the Shapaja section near Tarapoto (Peru; Boivin et al. 2018a). The latter section likely includes the Late Eocene-Early Oligocene transition, based on mammalian biostratigraphy, depositional environment sequence, stratigraphic correlation in the northern 
Peruvian foreland (Boivin et al. 2018a; Assemat et al. 2019), and preliminary chemostratigraphic analyses performed on bulk particulate organic carbon $\left(\delta^{13} \mathrm{C}_{\mathrm{org}}\right.$; work in progress $)$ of the sediments, which record isotopic trends similar to those observed at the global cooling of the Eocene-Oligocene transition (Yans in Antoine et al. in prep.). The age of Santa Rosa appears to be less constrained (see Introduction section, p. XX). Despite the presence in Santa Rosa of caviomorph taxa related to those of the Eocene localities of Contamana (Arnal et al. 2020), the age of this locality would be rather Early Oligocene due to the record of advanced taxa representatives of at least three of the four modern superfamilies of caviomorphs, such as Eoincamys (Chinchilloidea), Eodelphomys (Octodontoidea) or Eopululo (Erethizontoidea; Frailey and Campbell 2004; De Vries and Seiffert 2017; Boivin et al. 2019b). In accordance with the results of Assemat et al. (2019), the study of the new material from TAR-55/TAR-55bis and the revision of the former specimens attest to the full absence of taxa with such an advanced occlusal morphology in these localities, as well as in TAR-76 and TAR-77 (and TAR-56; see Assemat et al. 2019), even through dental fragments. However, by the presence of somewhat derived characters observed in Balsayacuy and Cc. aff. kummeli with respect to Canaanimys maquiensis and Cachiyacuy contamanensis (i.e., a metaloph absent or strongly reduced and lingually free), it would be possible that TAR-55/TAR-55bis, TAR-76 and TAR-77 document an interval of time slightly younger to CTA-27, i.e., documenting late Middle or early Late Eocene.

\section{Conclusion}

The study of new caviomorph material from TAR-55/TAR-55bis, TAR-76 and TAR-77 (Balsayacu) reveals the presence of four caviomorph taxa in these localities: Balsayacuy huallagaensis gen. et sp. nov., Cachiyacuy aff. kummeli and Caviomorpha gen. et sp. indet. 1 and 2. These four taxa show 
strong affinities with stem Caviomorpha recorded in pre-Deseadan localities in Peru (Eocene localities of Contamana plus Santa Rosa), and thus providing additional information regarding the paleodiversity of early low latitude caviomorphs of South America. In accordance with the results of a previous study of the fauna (Assemat et al. 2019), we propose an Eocene age for the Balsayacu section due to the absence of morphologically derived taxa, and notably the absence of representatives of the four modern superfamilies of Caviomorpha (contrary to younger localities such as TAR-49, TAR-50, those of the Shapaja section, and Santa Rosa). By the presence of somewhat derived characters in Balsayacuy and Cc. aff. kummeli with respect to Canaanimys maquiensis and Cachiyacuy contamanensis (CTA-27), the Balsayacu section may document a time interval during either late Middle or early Late Eocene times. Continuing field efforts in this Amazonian region of the Andean foothills should provide new critical paleontological data and thus new insights into the early evolutionary history and paleodiversity of that emblematic mammal group of South America, as well as other mammalian orders. Taxonomic-free age constraints such as provided by U/Pb datings on zircon grains on sandstones from the concerned sections would considerably add to the knowledge of the evolutionary dynamics of such puzzling African-Asian Paleogene incomers.

\section{References}

Antoine, Pierre-Olivier, Rodolfo, Salas-Gismondi, Patrice, Baby, Mouloud, Benammi, Stéphane, Brusset, Dario, De Franceschi, Nicolas, Espurt, Cyrielle, Goillot, François, Pujos, Julia, Tejada and Mario Urbina. 2007. The middle Miocene (Laventan) Fitzcarrald fauna, Amazonian Peru. In

Proceedings of the 4th EMPSLA, eds. Díaz-Martínez E. and Rábano I., 19-24. Cuadernos del Museo Geominero 8. 
Antoine, Pierre-Olivier, Laurent, Marivaux, Darin A., Croft, Guillaume, Billet, Morgan, Ganerød, Carlos, Jaramillo, Thomas, Martin, Maëva J., Orliac, Julia, Tejada, Ali J., Altamirano, Francis, Duranthon, Grégory, Fanjat, Sonia, Rousse and Rodolfo Salas-Gismondi. 2012. Middle Eocene rodents from Peruvian Amazonia reveal the pattern and timing of caviomorph origins and biogeography. Proceedings of the Royal Society of London B 279: 1319-1326.

Antoine, Pierre-Olivier, Martin, Roddaz, Stéphanie, Brichau, Julia, Tejada-Lara, Rodolfo, SalasGismondi, Ali, Altamirano, Mélanie, Louterbach, Luc, Lambs, Thierry, Otto and Stéphane Brusset. 2013. Middle Miocene vertebrates from the Amazonian Madre de Dios Subandean Zone, Perú. Journal of South American Earth Sciences 42: 91-102.

Antoine, Pierre-Olivier, M. Alejandra, Abello, Sylvain, Adnet, Ali J., Altamirano Sierra, Patrice, Baby, Guillaume, Billet, Myriam, Boivin, Ysabel, Calderón, Adriana, Candela, Jules, Chabain, Fernando, Corfu, Darin A. Croft, Morgan, Ganerød, Carlos, Jaramillo, Sebastian, Klaus, Laurent, Marivaux, Rosa E., Navarrete, Maëva J., Orliac, Francisco, Parra, María Encarnación, Pérez, François, Pujos, Jean-Claude, Anthony, Ravel, Céline, Robinet, Martin, Roddaz, Julia Victoria, Tejada-Lara, Jorge, Vélez-Juarbe, Frank P., Wesselingh and Rodolfo Salas-Gismondi. 2016. A 60-million-year Cenozoic history of western Amazonian ecosystems in Contamana, eastern Peru. Gondwana Research 31: 30-59.

Antoine, Pierre-Olivier, Rodolfo, Salas-Gismondi, François, Pujos, Morgan, Ganerød and Laurent Marivaux. 2017. Western Amazonia as a hotspot of mammalian biodiversity throughout the Cenozoic. In Proceedings of the Symposium Cenozoic Evolution of TRopical-Equatorial Mammals (IPC4), eds. Pierre-Olivier Antoine and François Pujos, 5-17. Journal of Mammalian Evolution 24.

Arnal, Michelle, Alejandro G., Kramarz, María G., Vucetich, Carl D., Frailey and Kenneth E. Campbell. 2020. New Palaeogene caviomorphs (Rodentia, Hystricognathi) from Santa Rosa, 
Peru: systematics, biochronology, biogeography and early evolutionary trends. Papers in Palaeontology 6: 193-216.

Assemat, Alexandre, Myriam, Boivin, Laurent, Marivaux, François, Pujos, Aldo, Benites-Palomino, Rodolfo, Salas-Gismondi, Julia V., Tejada-Lara, Rafael M., Varas-Malca, Francisco Ricardo, Negri, Ana Maria, Ribeiro and Pierre-Olivier Antoine. 2019. Restes inédits de rongeurs caviomorphes du Paléogène de la région de Juanjui (Amazonie péruvienne): systématique, implications macro-évolutives et biostratigraphiques. Geodiversitas 41: 699-730.

Bianucci, Giovanni, Olivier, Lambert, Rodolfo, Salas-Gismondi, Julia, Tejada, François, Pujos, Mario, Urbina and Pierre-Olivier Antoine. 2013. A Miocene relative of the Ganges River dolphin (Odontoceti, Platanistidae) from the Amazonian basin. Journal of Vertebrate Paleontology 33: $741-745$

Boivin, Myriam and Marivaux Laurent. 2020. Dental homologies and evolutionary transformations in Caviomorpha (Hystricognathi, Rodentia): new data from the Paleogene of Peruvian Amazonia. Historical Biology 32: 528-554.

Boivin, Myriam, Laurent, Marivaux, Maëva J., Orliac, François, Pujos, Rodolfo, Salas-Gismondi, Julia Victoria, Tejada-Lara and Pierre-Olivier Antoine. 2017a. Late middle Eocene caviomorph rodents from Contamana, Peruvian Amazonia. Palaeontologia Electronica 20.1.19A: 1-50.

Boivin, Myriam, Laurent, Marivaux, Adriana M., Candela, Maëva J., Orliac, François, Pujos, Rodolfo, Salas-Gismondi, Julia Victoria, Tejada-Lara and Pierre-Olivier Antoine. 2017b. Late Oligocene caviomorph rodents from Contamana, Peruvian Amazonia. Papers in Palaeontology 3: 69-109.

Boivin, Myriam, Laurent, Marivaux, François, Pujos, Rodolfo, Salas-Gismondi, Julia Victoria, Tejada-Lara, Rafael M., Varas-Malca and Pierre-Olivier Antoine. 2018a. Early Oligocene 
caviomorph rodents from Shapaja, Peruvian Amazonia. Palaeontographica, Abteilung A 311: 87156.

Boivin, Myriam, Samuel, Ginot, Laurent, Marivaux, Ali J., Altamirano-Sierra, François, Pujos, Rodolfo, Salas-Gismondi, Julia Victoria, Tejada-Lara and Pierre-Olivier Antoine. 2018b. Tarsal morphology and locomotor adaptation of some late middle Eocene caviomorph rodents from Peruvian Amazonia reveal early ecological diversity. Journal of Vertebrate Paleontology 38: e1555164.

Boivin, Myriam, Laurent, Marivaux, Rodolfo, Salas-Gismondi, Emma C., Vieytes and Pierre-Olivier Antoine. 2019a. Incisor enamel microstructure of Paleogene caviomorph rodents from Contamana and Shapaja (Peruvian Amazonia). Journal of Mammalian Evolution 26: 389-406.

Boivin, Myriam, Laurent, Marivaux and Pierre-Olivier Antoine. 2019b. L'apport du registre paléogène d'Amazonie sur la diversification initiale des Caviomorpha (Hystricognathi, Rodentia) : implications phylogénétiques, macroévolutives et paléobiogéographiques. Geodiversitas 41: $143-245$.

Bond, Mariano, Marcelo F., Tejedor, Kenneth E., Campbell, Laura, Chornogubsky, Nelson, Novo and Francisco Goin. 2015. Eocene primates of South America and the African origins of New World monkeys. Nature 520: 538-541.

Bowdich, Thomas Edward. 1821. An analysis of the natural classifications of Mammalia: for the use of students and travellers. J. Smith.

Campbell, Kenneth E. 2004. The Paleogene mammalian fauna of Santa Rosa, Amazonian Peru. Natural History Museum of Los Angeles County, Science Series 40.

Campbell, Kenneth E., Carl D., Frailey and Lidia Romero-Pittman. 2000. The Late Miocene gomphothere Amahuacatherium peruvium (Proboscidea: Gomphotheriidae) from Amazonian 
Peru: implications for the Great American Faunal Interchange. Boletín del INGEMMET 23: 1152.

Campbell, Kenneth E., Matt, Heizler, Carl D., Frailey, Lidia, Romero-Pittman and Donald R Prothero. 2001. Upper Cenozoic chronostratigraphy of the southwestern Amazon Basin. Geology 297: 595-598.

Campbell, Kenneth E., Carl D., Frailey and Lidia Romero-Pittman. 2006. The Pan-Amazonian Ucayali Peneplain, Late Neogene sedimentation in Amazonia, and the birth of the modern Amazon River system. Palaeogeography, Palaeoclimatology, Palaeoecology 239: 166-219.

Campbell, Kenneth E., Donald R., Prothero, Lidia, Romero-Pittman, Fritz, Hertel and Nadia Rivera. 2010. Amazonian magnetostratigraphy: dating the first pulse of the Great American Faunal Interchange. Journal of South American Earth Sciences 29: 619-626.

Chabain, Jules, Pierre-Olivier, Antoine, Ali J., Altamirano-Sierra, Laurent, Marivaux, François, Pujos, Rodolfo, Salas Gismondi and Sylvain Adnet. 2017. Cenozoic batoids from Contamana (Peruvian Amazonia) with focus on freshwater potamotrygonins and their paleoenvironmental significance. Geobios 50: 389-400.

Croft, Darin A., John J., Flynn and André R. Wyss. 2008. The Tinguiririca Fauna of Chile and the early stages of "modernization" of South American mammal faunas. Arquivos do Museu Nacional 66: 191-211.

De Vries, Dorien and Erik R. Seiffert. 2017. Bayesian Tip-dating of Caviomorph Rodent Phylogenies provides New Age Estimates for South America's oldest Platyrrhines. Program of the 86th Annual Meeting of the American Association of Physical Anthropologists (New Orleans, Unites States). American Journal of Physical Anthropologists 162: 161-162. 
Frailey, Carl D. 1986. Late Miocene and Holocene mammals, exclusive of the Notoungulata, of the Río Acre region, Western Amazonia. Natural History Museum of Los Angeles County Contribution in Science 374: 1-46.

Frailey, Carl D. and Kenneth E. Campbell. 2004. Paleogene rodents from Amazonian Peru: the Santa Rosa local fauna. In The Paleogene Mammalian Fauna of Santa Rosa, Amazonian Peru, ed. Kenneth E. Campbell, 71-130. Natural History Museum of Los Angeles County, Science Series 40.

Goillot, Cyrielle, Pierre-Olivier, Antoine, Julia, Tejada, François, Pujos and Rodolfo SalasGismondi. 2011. Middle Miocene Uruguaytheriinae (Mammalia, Astrapotheria) from Peruvian Amazonia and a review of the astrapotheriid fossil record in northern South America. Geodiversitas 33: 331-345.

Hoorn, Carina, Frank P., Wesselingh, Hans, Ter Steege, Mauricio A., Bermúdez, Andres, Mora, Jan, Sevink, Isabel, Sanmartín, Andrea, Sanchez-Meseguer, Cajsa Lisa, Anderson, Jorge de Jesus Picanço de Figueiredo, Carlos, Jaramillo, Douglas, Riff, Francisco Ricardo, Negri, Henri, Hooghiemstra, John, Lundberg, Thomas, Städler, Tilina, Särkinen and Alexandre Antonelli. 2010. Amazonia through time: Andean uplift, climate change, landscape evolution, and biodiversity. Science 330: 927-931.

Huchon, Dorothée, François M., Catzeflis and Emmanuel J.P. Douzery. 2000. Variance of molecular datings, evolution of rodents, and the phylogenetic affinities between Ctenodactylidae and Hystricognathi. Proceedings of the Royal Society of London. Series B: Biological Sciences 267: $393-402$.

Jenkins, Clinton N., Pimm, Stuart L. and Lucas N. Joppa. 2013. Global patterns of terrestrial vertebrate diversity and conservation. Proceedings of the National Academy of Sciences 110: E2602-E2610. 
Kay, Richard F. 2015. New World monkey origins. Science 347: 1068-1069.

Kerber, Leonardo, Francisco Ricardo, Negri, Ana Maria, Ribeiro, Norma, Nasif, Jonas Pereira, Souza-Filho and Jorge Ferigolo. 2017. Tropical fossil caviomorph rodents from the southwestern Brazilian Amazonia in the context of the South American faunas: systematics, biochronology, and paleobiogeography. Journal of Mammalian Evolution 24: 57-70.

Marivaux, Laurent and Myriam Boivin. 2019. Emergence of hystricognathous rodents: Palaeogene fossil record, phylogeny, dental evolution and historical biogeography. Zoological Journal of the Linnean Society 187: 929-964.

Marivaux, Laurent, Rodolfo, Salas-Gismondi, Julia, Tejada, Guillaume, Billet, Mélanie, Louterbach, Jochem, Vink, Julien, Bailleul, Martin, Roddaz and Pierre-Olivier Antoine. 2012a. A platyrrhine talus from the early Miocene of Peru (Amazonian Madre de Dios Sub-Andean Zone). Journal of Human Evolution 63: 696-703.

Marivaux, Laurent, Sylvain, Adnet, Ali J., Altamirano-Sierra, Myriam, Boivin, François, Pujos, Anusha, Ramdarshan, Rodolfo, Salas-Gismondi, Julia V., Tejada-Lara and Pierre-Olivier Antoine. 2016a. Neotropics provide insights into the emergence of New World monkeys: new dental evidence from the late Oligocene of Peruvian Amazonia. Journal of Human Evolution 97: $159-175$.

Marivaux, Laurent, Sylvain, Adnet, Ali J., Altamirano-Sierra, François, Pujos, Anusha, Ramdarshan, Rodolfo, Salas-Gismondi, Julia V., Tejada-Lara and Pierre-Olivier Antoine. 2016b. Dental remains of cebid platyrrhines from the earliest late Miocene of Western Amazonia, Peru: macroevolutionary implications on the extant capuchin and marmoset lineages. American Journal of Physical Anthropology 161: 478-493.

Marivaux, Laurent, Walter, Aguirre-Diaz, Aldo, Benites-Palomino, Guillaume, Billet, Myriam, Boivin, François, Pujos, Rodolfo, Salas-Gismondi, Julia Victoria, Tejada-Lara, Rafael M., Varas- 
Malca and Pierre-Olivier Antoine. 2020. New record of Neosaimiri (Cebidae, Platyrrhini) from the late Middle Miocene of Peruvian Amazonia. Journal of Human Evolution 146: 102835.

Negri, Francisco Ricardo, Jean, Bocquentin-Villanueva, Jorge, Ferigolo and Pierre-Olivier Antoine. 2010. A review of Tertiary mammal faunas and birds from western Amazonia. In Amazonia, Landscape and Species Evolution: A Look into the Past, eds. Carina Hoorn and Frank P. Wesselingh, 245-258. Blackwell-Wiley, Hoboken.

François, Pujos, Rodolfo, Salas-Gismondi, Guillaume, Baby, Patrice, Baby, Goillot Cyrielle, Julia, Tejada and Pierre-Olivier Antoine. 2013. Implication of the presence of Megathericulus (Xenarthra: Tardigrada: Megatheriidae) in the Laventan of Peruvian Amazonia. Journal of Systematic Palaeontolology 11: 973-991.

Rohlf, F. James. 2016. Tps Series. Department of Ecology and Evolution, State University of New York at Stony Brook, Stony Brook.

Shockey, Bruce J., Ralph, Hitz and Mariano Bond. 2004. Paleogene notoungulates from the Amazon Basin of Peru. In The Paleogene Mammalian Fauna of Santa Rosa, Amazonian Peru, ed. Kenneth E. Campbell, 61-70. Natural History Museum of Los Angeles County, Science Series 40.

Seiffert, Erik R., Tejedor, Marcelo F., John G., Fleagle, Nelson M., Novo, Fanny M., Cornejo, Mariano, Bond, Dorien, De Vries and Kenneth E. Campbell. 2020. A parapithecid stem anthropoid of African origin in the Paleogene of South America. Science 368: 194-197.

Stebbins, G. Ledyard. 1974. Flowering plants: evolution above the species level. The Belknap Press of Harvard University Press, Cambridge, MA, USA.

Tejada-Lara, Julia Victoria, Rodolfo, Salas-Gismondi, François, Pujos, Patrice, Baby, Mouloud, Benammi, Stéphane, Brusset, Dario, De Franceschi, Nicolas, Espurt, Mario, Urbina and PierreOlivier Antoine. 2015. Life in protoamazonia: Middle Miocene mammals from the Fitzcarrald Arch (Peruvian Amazonia). Palaeontology 58: 341-378. 
Tullberg, Tycho. 1899. Ueber das System der Nagethiere: eine phylogenetische Studie. Nova Acta Regiae Societatis Scientiarum Upsaliensis 18: 1-514.

Vucetich, María Guiomar, Emma C., Vieytes, María Encarnación, Pérez and Alfredo A. Carlini. 2010. The rodents from La Cantera and the early evolution of caviomorphs in South America. In The Paleontology of Gran Barranca, Evolution and Environmental Change through the Middle Cenozoic of Patagonia, eds. Richard H. Madden, Alfredo A. Carlini, María Guiomar Vucetich and Richard F. Kay, 189-201. Cambridge University Press, Cambridge.

Vucetich, María G., Michelle, Arnal, Cecilia M., Deschamps, María Encarnación, Pérez and Emma C. Vieytes. 2015. A brief history of caviomorph rodents as told by the fossil record. In Biology of Caviomorph Rodents: Diversity and Evolution, eds. Aldo I. Vassallo and Daniel Antenucci, 1162. Sociedad Argentina para el Estudio de los Mamíferos (SAREM), Buenos Aires, Argentina.

Wood, Albert E. 1955. A revised classification of the rodents. Journal of Mammalogy 36: 165-187. 

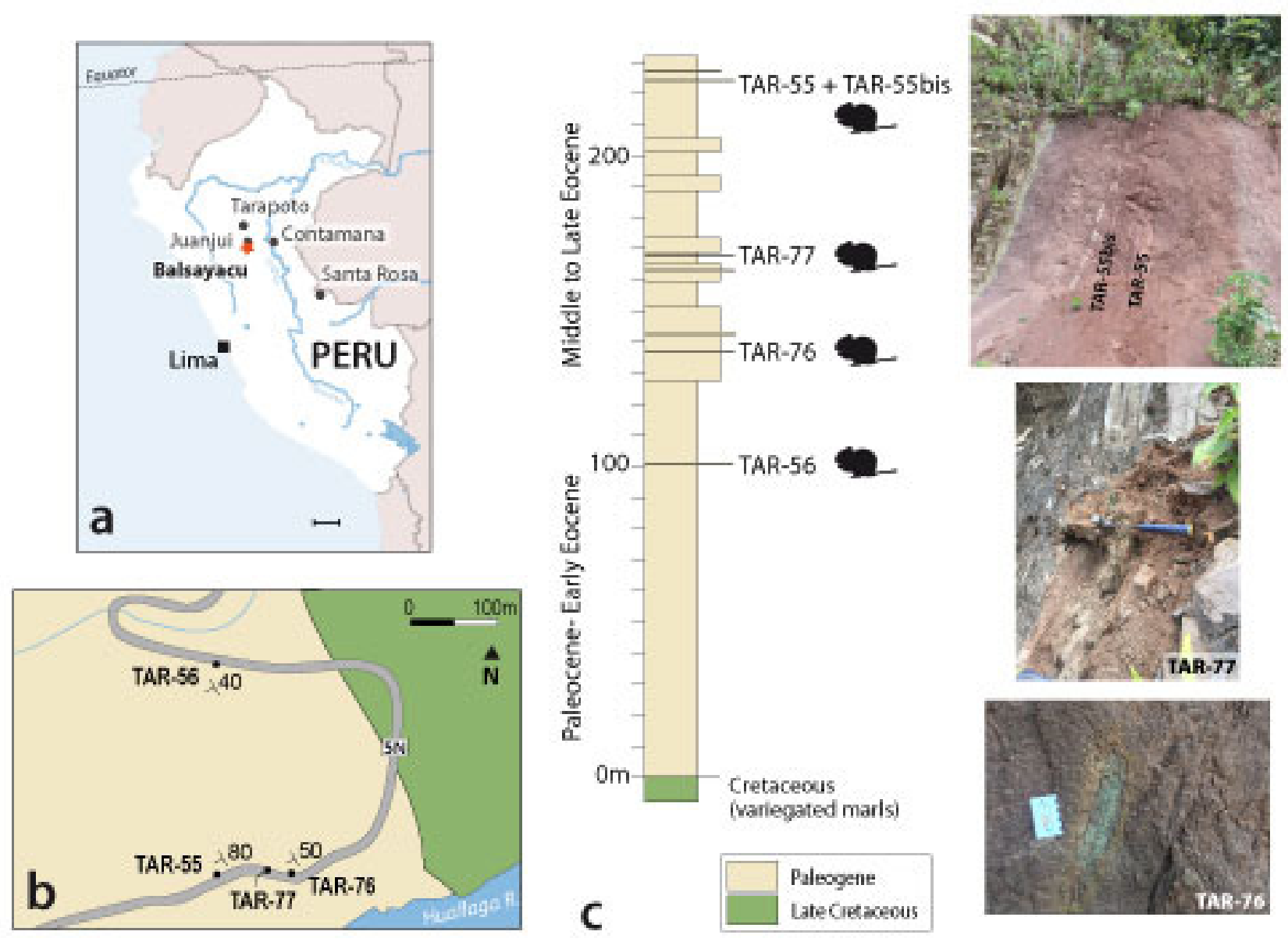

Fig. 1 Geographic location and stratigraphy of TAR-76, TAR-77, TAR-55 and TAR-55bis localities (Balsayacu, Peru; late Middle or early Late Eocene). a general map of Peru with the Balsayacu area (San Martín Department; star symbol) and the other pre-Deseadan localities yielding caviomorphs in Amazonia (circle symbols): Contamana area (Loreto Department; late Middle Eocene; Antoine et al. 2012; Boivin et al. 2017), Juanjui area (late Middle Eocene-Early Oligocene; Assemat et al. 2019), Tarapoto area (Shapaja section; San Martín Department; Late Eocene-Early Oligocene; Boivin et al. 2018) and Santa Rosa (Ucayali Department; ?Late Eocene/Early Oligocene; Frailey and Campbell 2004; Arnal et al. 2020). Scale bar: $100 \mathrm{~km}$. b simplified geological map of the Balsayacu area. Scale bar: $100 \mathrm{~m}$. c synthetic stratigraphic section of Balsayacu with the position of the rodent-bearing localities TAR-56, TAR-76, TAR-77, TAR-55 and TAR-55bis, and photos of the last four localities. Modified from Assemat et al. (2019). 


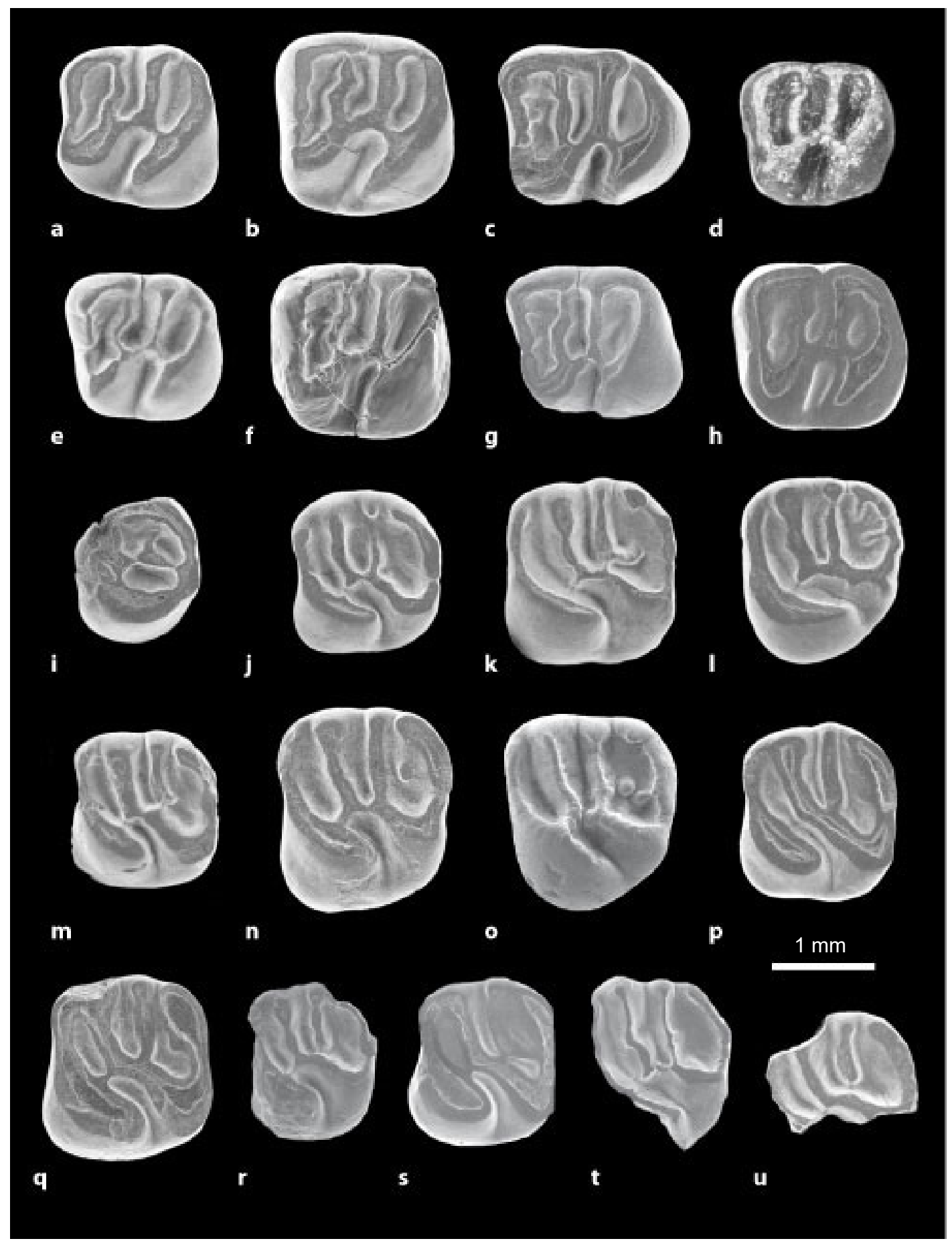

Fig. 2 Scanning electron microscope images (in occlusal view) of Balsayacuy huallagaensis gen. et sp. nov. from TAR-55/TAR-55bis and TAR-77 (Balsayacu, San Martín Department, Peru; late Middle or early Late Eocene). a-c, e-p from TAR-55/TAR-55bis and d from TAR-77. a MUSM 3922, right $\mathrm{m} 1$ (reversed); b MUSM 3926, right $\mathrm{m} 2$ (reversed); c MUSM 3928, left m3; d MUSM 3921, left m1; e MUSM 3923, right $\mathrm{m} 1$ (reversed); f MUSM 3927, right m2 (reversed); g MUSM 3373, left m1; h MUSM 3924, left m2; i MUSM 3929, right P4 (reversed); j MUSM 3931, left M1; k MUSM 3935, left M2; I MUSM 3938, right M3 (reversed); m MUSM 3933, left M1; n MUSM 3937, right M2 (reversed); o MUSM 3371, left M3; p MUSM 3932, left M1; q MUSM 3936, left M2; r MUSM 3371, right M1 (reversed); s MUSM 3378, left M2; t MUSM 3379, left M3; u MUSM 3930, labial fragment of right $M$ (reversed). 


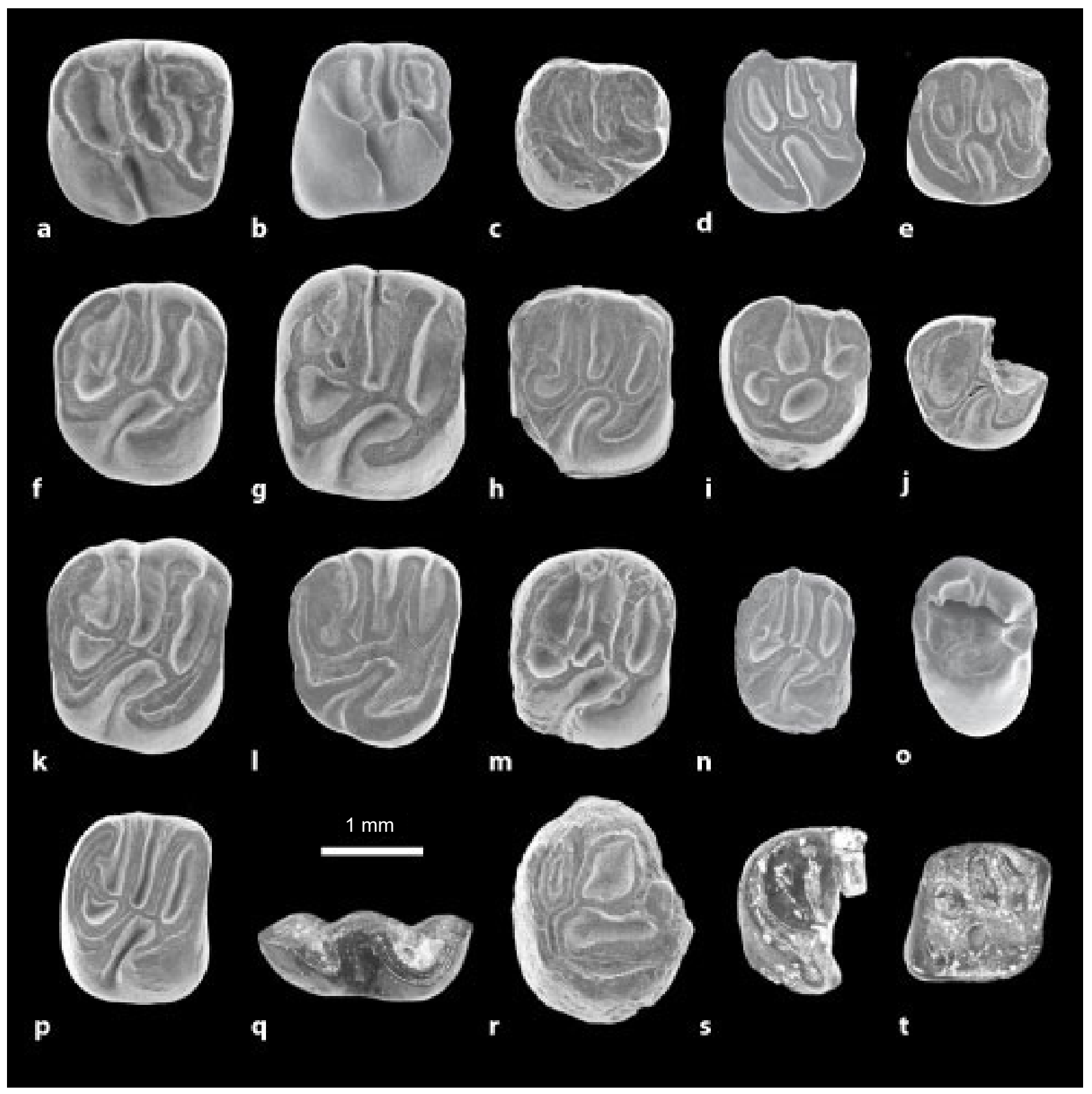

Fig. 3 Scanning electron microscope images (in occlusal view) of fossil caviomorph teeth from the Eocene Peruvian localities (CTA-27, TAR-55/TAR-55bis, and TAR-76). a-o Cachiyacuy aff. kummeli from TAR-55/TAR-55bis. p Cachiyacuy kummeli from CTA-27. q, r Caviomorpha gen. et sp. indet. 1 from TAR-55/TAR-55bis. s, t Caviomorpha gen. et sp. indet. 2 from TAR-76. a MUSM 3910, right $\mathrm{m} 2$; b MUSM 3374, right $\mathrm{m1}$; c MUSM 3907, right p4; d MUSM 3375, right m1; e MUSM 3908, left $\mathrm{m} 1$ (reversed); f MUSM 3919, right M3; g MUSM 3917, right M2; h MUSM 3915, right M1; i MUSM 3913, right P4; j MUSM 3911, left dP4 (reversed); k MUSM 3918, right M2; I MUSM 3920, right M3; m MUSM 3916, left M2 (reversed); n MUSM 3376, left M1 (reversed); o MUSM 3372, left P4 (reversed); p MUSM 3943, left M2 (reversed); q MUSM 3939, labial fragment of right m; r MUSM 3940, left P4 (reversed); s MUSM 3941, posterior fragment of left p4 (reversed); $\mathbf{t}$ MUSM 3942, right $\mathrm{m} 1$ or $\mathrm{m} 2$. 